\title{
Mechanism of Androgen Receptor Corepression by CKßBP2/ CRIF1, a Multifunctional Transcription Factor Coregulator Expressed in Prostate Cancer
}

\author{
Jiann-an Tan ${ }^{\mathrm{a}}$, Suxia Bai ${ }^{\mathrm{a}, \#}$, Gail Grossman ${ }^{\mathrm{a}}$, Mark A. Titus ${ }^{\mathrm{b}}$, O. Harris Ford ${ }^{\mathrm{c}}$, Elena A. \\ Pop $^{b}$, Gary J. Smith ${ }^{b}$, James L. Mohler ${ }^{b, c, d}$, Elizabeth M. Wilson ${ }^{a, c, e}$, and Frank S. French ${ }^{a, c,}{ }^{*}$ \\ aLaboratories for Reproductive Biology, Department of Pediatrics, University of North Carolina, \\ School of Medicine, Chapel Hill, NC \\ bDepartment of Urology, Roswell Park Cancer Institute, Buffalo, NY \\ 'Lineberger Comprehensive Cancer Center, University of North Carolina, School of Medicine, \\ Chapel Hill, NC \\ dDepartment of Urology, University of Buffalo School of Medicine and Biotechnology, Buffalo, NY \\ eDepartment of Biochemistry and Biophysics, University of North Carolina, School of Medicine, \\ Chapel Hill, NC
}

\begin{abstract}
The transcription factor coregulator Casein kinase II $\beta$ binding protein 2 or CR6-interacting factor 1 (CK $\beta B P 2 / C R I F 1)$ binds the androgen receptor (AR) in prostate cancer cells and in response to dihydrotestosterone localizes with $\mathrm{AR}$ on the prostate-specific antigen gene enhancer, but does not bind DNA suggesting CK $\beta$ BP2/CRIF1 localization in chromatin is determined by AR. In this study we show also that CK $\beta B P 2 / C R I F 1$ inhibits wild-type AR and AR N-terminal transcriptional activity, binds to the AR C-terminal region, inhibits interaction of the $\mathrm{AR} \mathrm{N}$ - and C-terminal domains (N/C interaction) and competes with p160 coactivator binding to the AR C-terminal domain, suggesting CK $\beta$ BP2/CRIF1 interferes with AR activation functions 1 and 2. CK $\beta B P 2 /$ CRIF1 is expressed mainly in stromal cells of benign prostatic hyperplasia and in stroma and epithelium of prostate cancer. CK $\beta B P 2 / C R I F 1$ protein is increased in epithelium of androgendependent prostate cancer compared to benign prostatic hyperplasia and decreased slightly in castration recurrent epithelium compared to androgen-dependent prostate cancer. The multifunctional CK $\beta \mathrm{BP} 2 / \mathrm{CRIF} 1$ is a STAT3 interacting protein and reported to be a coactivator of STAT3. CK $\beta B P 2 / C R I F 1$ is expressed with STAT3 in prostate cancer where STAT3 may help to offset the AR repressor effect of CK $\beta B P 2 / C R I F 1$ and allow AR regulation of prostate cancer growth.
\end{abstract}

(C) 2013 Elsevier Ireland Ltd. All rights reserved.

*Address correspondence to Frank S. French, M.D., Laboratories for Reproductive Biology, Department of Pediatrics, University of North Carolina School of Medicine, Chapel Hill, NC 27599-7500, TEL 919-966-0930, Fax 919-966-2203, fsfrench@ med.unc.edu. \#Present address: Janelia Farm Research Campus, Howard Hughes Medical Institute, Ashburn, VA

Publisher's Disclaimer: This is a PDF file of an unedited manuscript that has been accepted for publication. As a service to our customers we are providing this early version of the manuscript. The manuscript will undergo copyediting, typesetting, and review of the resulting proof before it is published in its final citable form. Please note that during the production process errors may be discovered which could affect the content, and all legal disclaimers that apply to the journal pertain. 


\section{Keywords}

androgen receptor; dihydrotestosterone; benign prostatic hyperplasia; prostate cancer; transcription coactivators and corepressors; protein kinase CK2 binding protein 2; CR6 interacting factor-1; signal transducer and activator of transcription 3

\section{Introduction}

The androgen receptor (AR) has an essential role in human male reproductive tract development and function as evidenced by AR gene mutations that result in the androgen insensitivity syndrome (Quigley et al., 1995). AR is a DNA binding transcription factor that directs the cellular actions of androgens by acting as a docking platform for transcription coregulators. Epithelium and stroma of human prostate are targets of androgen action and depend on AR and its natural ligand, dihydrotestosterone (DHT) for growth and male sexual development. Similarly, neoplastic growth of the prostate is AR dependent and regresses initially in response to androgen deprivation therapy. Evidence indicates that AR has a central role in the eventual relapse of prostate cancer during androgen deprivation therapy (referred to as castration-recurrent or castration-resistant growth) (Grossman et al., 2001; Gregory et al., 2001a, 2001b; Ponguta et al., 2008; Mohler et al., 2004; Titus et al., 2005; Yuan and Balk, 2009; Agoulnik and Weigel, 2006; Heemers and Tindall, 2007). Transcriptional functions of AR involve the concerted actions of coactivators and corepressors (Heemers and Tindall, 2007; Wang et al., 2005; Burd et al., 2006) that regulate chromatin modifying complexes and gene transcription (reviewed in Perissi et al., 2010; Battaglia et al., 2010)

CK $\beta$ BP2/CRIF1 cDNA was isolated originally in p53 stably transformed colon cancer cell lines (Horikoshi et al., 1999) and later identified as a protein that interacts with the $\beta$ subunit of protein kinase CK2 (Ahn et al., 2001), but its influence on the function of protein kinase CK2 remains unknown. CK $\beta B P 2 / C R I F 1$ was identified also as one of a number of papilloma virus L2 interacting nuclear proteins (Gornemann et al., 2002). Indication of a function for CK $\beta B P 2 / C R I F 1$ was revealed when Chung et al. (2003) reported CK $\beta B P 2 /$ CRIF1 is a GADD45 $\gamma$ binding protein. GADD45a, $\beta$ and $\gamma$ are DNA damage inducible proteins (Carrier et al., 1999) that inhibit the cell cycle. CK $\beta B P 2 / C R I F 1$ interacted with GADD45 $\gamma$ and had a similar function with respect to cell cycle inhibition (Chung et al., 2003).

Here we report a mechanism for the AR corepressor activity of CK $\beta B P 2 / C R I F 1$ (Su JH et al. 2008) and identify a small fragment of CK $\beta B P 2 / C R I F 1$ that inhibits the transcriptional activity of AR. CK $\beta B P 2 / C R I F 1$ interacted with the $\mathrm{C}$ - and $\mathrm{N}$-terminal regions of $\mathrm{AR}$, disrupted the AR N/C interaction and competed with TIF2 binding to the AR C-terminus. CKßBP2/CRIF1 also inhibited the constitutive activity of an AR N-terminal-DNA binding domain fragment. CK $\beta \mathrm{BP} 2 / \mathrm{CRIF} 1$ protein expression was analyzed in prostate cancer where AR has a major role in neoplastic growth and progression. In benign prostatic hyperplasia, CK $\beta B P 2 / C R I F 1$ protein was expressed mainly in fibromuscular stromal cells. In androgendependent prostate cancer, CK $\beta \mathrm{BP} 2 / \mathrm{CRIF} 1$ protein was increased in epithelial cells compared to benign prostatic hyperplasia. However, it was reduced in epithelial cells of castration-recurrent compared to androgen-dependent prostate cancer.

STAT3 is known to promote prostate cancer progression. In prostate cancer tissue microarrays, we show that CK $\beta \mathrm{BP} 2 / \mathrm{CRIF} 1$ and STAT3 proteins are present in the same cellular locations. CK $\beta B P 2 / C R I F 1$ is a STAT3 coactivator (Kwon et al., 2008). CK $\beta$ BP2/ 
CRIF1 binding and coactivation of STAT3 may offset the AR repressor effect of CK $\beta B P 2 /$

CRIF1 and help maintain a selective advantage for prostate cancer cell growth.

\section{Materials And Methods}

\subsection{Yeast two hybrid screening}

The AR vector pBDGAL4CAM-481-919 that expresses the carboxyl-terminal portion of the human AR N-terminal, DNA and ligand-binding domains was used as bait in yeast twohybrid screening of a human epithelial cervical carcinoma HeLa cell cDNA library in GADGH (Clontech Laboratories, Inc., Palo Alto, CA) (gift of Yue Xiong, University of North Carolina at Chapel Hill). Yeast strain Hf7c co-transformed with HeLa cell cDNAs was plated on synthetic medium without Leu, Trp and His containing $5 \mathrm{mM} 3$-amino-1,2,4triazole and $1 \mu \mathrm{M}$ DHT. After 5 to 7 days in culture, colonies were selected for $\beta$ galactosidase assay. cDNAs from $\beta$ galactosidase positive yeast colonies were rescued using standard procedures. Liquid $\beta$ galactosidase assays were performed as described for the Clontech Matchmaker system (Clontech protocol PT3247-1).

\subsection{Plasmids}

The coding region for CK $\beta$ BP2/CRIF1 was excised from pGAD-GH using EcoRI and XhoI and cloned into the same restriction sites in pSG5 (Stratagene) with a FLAG tag added to make pSGFLAG-CKßBP2/CRIF1-7-222. pSG5 (pSG) was chosen for these studies because its SV40 promoter was not affected by pSGFLAG-CK $\beta B P 2 / C R I F 1$, whereas the activity of a CMV promoter was increased by pSGFLAG-CK $\beta$ BP2/CRIF1. The cytomegalovirusluciferase reporter vector was provided by William M. Wood and Arthur GutierrezHartmann and SV40-luciferase was from Stratagene. pSGFLAG-CK $\beta B P 2 / C R I F 1-7-222$ was digested with PstI, gel purified and the $6 \mathrm{~kb}$ fragment self-ligated to create pSGFLAGCKßBP2/CRIF1-7-157. The small PstI fragment was treated with T4 DNA polymerase and cloned into pSGFLAG EcoRV to create pSGFLAG-CKßBP2/CRIF1-158-206. Full-length CKßBP2/CRIF1 was obtained from ATCC (catalog \#6709344). pOBT7 containing fulllength CK $\beta B P 2 / C R I F 1$ was digested with EcoRI, treated with Klenow and digested with XhoI. The full-length fragment was cloned into pSGFLAG treated with BamHI, filled-in with Klenow followed by XhoI digestion to make pSGFLAG-CKßBP2/CRIF1-2-222. The full-length clone does not contain the codon T187C missense mutation we found in the pSGFLAG-CKßBP2/CRIF1-7-222 isolated by yeast two-hybrid screening. Human AR expression vectors GAL-AR-624-919, VP-AR-1-660 and VP-TIF2.1 (TIF2-624-1287) were described (Tan et al., 2000; He et al., 1999). The prostate-specific antigen (PSA) luciferase (Luc) reporter vector PSA-Enh-Luc provided by Michael Carey, University of California at Los Angeles, contains the PSA upstream enhancer region (Huang et al., 1999). MMTV-Luc reporter gene was provided by Stanley M. Hollenberg and Ron M. Evans (Salk Institute).

\subsection{Transient cotransfection assay}

Cotransfection assays were performed in triplicate (Tan et al., 2000; He et al., 1999; Bai et al., 2005, 2008). In brief, African green monkey kidney CV1 cells were maintained in $10 \%$ fetal bovine serum containing high glucose and antibiotics. Cells $\left(4.2 \times 10^{5}\right)$ were plated in $6 \mathrm{~cm}\left(28 \mathrm{~cm}^{2}\right)$ culture dishes. On the following day when $70-80 \%$ confluent, cells were transfected with MMTV-Luc $(0.5 \mu \mathrm{g})$ and various amounts of expression vectors using the $\mathrm{CaPO}_{4}$ method. After 15\% glycerol shock for 4 min, cells were incubated in Dulbecco's modified Eagle's medium-H (DMEM-H) without phenol red and serum in the absence and presence of DHT. The next day media were removed and replaced with fresh media of the same composition. Incubation was continued for $20 \mathrm{~h}$. Cells were harvested in lysis buffer and luciferase activity was measured in an automated multiwell luminometer. Results are 
representative of at least three individual experiments performed in triplicate. Error bars represent \pm SEM.

CWR-R1 cells were maintained in Richter's improved minimal essential medium (Irvine Scientific, Santa Ana, CA) supplemented with $10 \mathrm{mM}$ nicotinamide, $5 \mu \mathrm{g} / \mathrm{ml}$ insulin, $5 \mu \mathrm{g} /$ $\mathrm{ml}$ transferrin, $5 \mathrm{ng} / \mathrm{ml}$ selenium, $100 \mathrm{units} / \mathrm{ml}$ penicillin, $100 \mu \mathrm{g} / \mathrm{ml}$ streptomycin and $2 \%$ fetal bovine serum. Cells were plated in 6 well plates $\left(3.5 \times 10^{6}\right.$ cells per well). Two hybrid interaction assays were performed in HeLa cells (Bai et al., 2005, 2008; Gregory et al., 2004) maintained in Eagle's minimum essential medium supplemented with $10 \%$ fetal bovine serum (Gemini or Hyclone), penicillin, streptomycin and $2 \mathrm{mM} \mathrm{L}$-glutamine. HeLa cells $\left(5 \times 10^{4}\right.$ cells/well in 12 well plates) were transfected with $0.1 \mu \mathrm{g}$ of $5 \times$ GAL4Luc3, 50 ng of VP-AR-1-660 or VP-TIF2.1-624-1287 and $50 \mathrm{ng}$ GAL-AR-624-919. DNA was added to $43 \mu \mathrm{l}$ of serum-free medium and $0.6 \mu \mathrm{l}$ of FuGENE-6 reagent per well. After $15 \mathrm{~min}$ incubation, $40 \mu \mathrm{l}$ of FuGENE DNA mixture was added to each well containing $1 \mathrm{ml}$ medium. The next day, cells were washed with phosphate buffered saline (PBS) and $1 \mathrm{ml} /$ well serum-free medium lacking phenol red and containing the indicated steroids was added and incubated overnight at $37^{\circ} \mathrm{C}$. The next day cells were washed with PBS and assayed for luciferase activity after harvesting in $0.25 \mathrm{ml}$ lysis buffer.

\subsection{Glutathione S-transferase (GST) pull-down assays}

GST binding assays were performed as described (Tan et al., 2000). In brief, pSGFLAGCKßBP2/CRIF1 was incubated with $\left[{ }^{35}\right.$ S]methionine and rabbit reticulocyte lysate using the TnT T7 Quick-coupled Transcription/Translation System kit (Promega). Labeled protein was distributed equally among incubations with GST-glutathione-Sepharose control and recombinant GST-fusion proteins bound to glutathione-Sepharose. After incubation and washes in the presence of $0.1 \mathrm{nM}$ DHT, labeled protein was eluted by boiling in SDS buffer and separated by SDS-PAGE. Gels were dried and exposed to Kodak x-ray film.

\subsection{Coimmunoprecipitation}

COS cells cultured in Dulbecco's modified Eagle's medium-H in $10 \mathrm{~cm}$ dishes were transfected with pSGFLAG-CK $\beta$ BP2/CRIF1-7-222, -7-157 or -158-206 in combination with pSG-AR using the DEAE-dextran method (Tan et al., 2000). Two days after transfection, cells were harvested in PBS and lysed in $50 \mathrm{mM}$ Tris, $\mathrm{pH} 7.4,150 \mathrm{mM} \mathrm{NaCl}, 0.5 \% \mathrm{NP} 40$, $50 \mathrm{mM} \mathrm{NaF}$ with the addition of $0.8 \mathrm{mM}$ DTT, $1 \mathrm{mM}$ PMSF and a protease inhibitor cocktail pellet (Roche). $25 \mu 1$ anti-FLAG M2 agarose gel (Sigma) was added and incubated overnight at $4^{\circ} \mathrm{C}$. Beads were washed several times with lysis buffer and bound proteins eluted in SDS sample buffer, separated in SDS-PAGE and western blotted using FLAG M2 or AR32 antibody (Quarmby et al., 1990). The FLAG-STAT3 expression vector was pRC/ CMV-STAT3 from Addgene.

\subsection{Immunofluorescence microscopy}

COS cells seeded on cover slips in 12 -well plates $(1.25 \times 105$ cells/well $)$ were transfected using the Effectene method with $0.1 \mu \mathrm{g}$ pCMV-AR, pSGFLAG-CKßBP2/CRIF1 or pSGFLAG in the presence and absence of DHT as described (Bai et al., 2005). Cells were fixed in 3\% paraformaldehyde in PBS for $10 \mathrm{~min}$ at room temperature and permeabilized with $0.2 \%$ Triton X-100 in PBS for 5 min at $4{ }^{\circ} \mathrm{C}$. After rinsing with PBS 3 times, $0.5 \%$ bovine serum albumin in PBS was added and cells incubated $30 \mathrm{~min}$ at room temperature. Cells were incubated with primary antibodies anti-AR Abcam ab3510 (1:250 dilution) and/ or anti-FLAG (1:1000 dilution) for $1 \mathrm{~h}$ at room temperature. After washing with PBS, a 1:50 dilution of secondary fluorescent antibody was added and incubated for $30 \mathrm{~min}$. Microscopy was performed using an Olympus BX60 microscope with 40× objective, magnification 400x. Rabbit anti-AR ab3510 was from Abcam, Cambridge, MA. Mouse anti-FLAG 
antibody was from Sigma. Fluorescein (FITC)-conjugated AffiniPure donkey anti-rabbit $\mathrm{IgG}$ and rhodamine (TRITC)-conjugated AffiniPure donkey anti-mouse IgG were from Jackson ImmunoResearch, West Grove PA.

\subsection{Chromatin immunoprecipitation}

CWR-R1 human prostate cancer cells $\left(10^{7} / 10 \mathrm{~cm}\right.$ dish) were serum starved for $24 \mathrm{~h}$. The next day, cells were changed to serum-free medium containing $10 \mathrm{nM}$ methyltrienolone (R1881), incubated for various times and cross-linked using $1 \%$ formaldehyde for $10 \mathrm{~min}$ at room temperature followed by $5 \mathrm{~min}$ with $0.125 \mathrm{M}$ glycine at room temperature. Cells were washed and harvested in PBS. Cell pellets were resuspended in $10 \mathrm{mM}$ Hepes, $\mathrm{pH} 7.9,0.5 \%$ Triton X-100, $1.5 \mathrm{mM} \mathrm{MgCl}_{2}, 10 \mathrm{mM} \mathrm{KCl}, 0.6 \mathrm{mM}$ phenylmethylsulfonyl fluoride, $2.5 \mathrm{nM}$ pepstatin A, $30 \mathrm{nM}$ leupeptin and $0.5 \mathrm{mM}$ DTT. After a $10 \mathrm{~min}$ incubation at $4^{\circ} \mathrm{C}$, cell pellets were resuspended in $20 \mathrm{mM}$ Hepes, $\mathrm{pH} 7.9,25 \%$ glycerol, $0.5 \%$ Triton X-100, 0.42 $\mathrm{M} \mathrm{NaCl}, 1.5 \mathrm{mM} \mathrm{MgCl} 2,0.2 \mathrm{mM}$ EDTA with the same amount of proteinase inhibitors. Following $20 \mathrm{~min}$ incubation at $4^{\circ} \mathrm{C}$, cells were sonicated at $21 \%$ power 40 times, $0.5 \mathrm{sec}$ each time and the procedure repeated to obtain 100-1000-bp DNA fragments. Following 10 min centrifugation, clarified lysates were diluted $1: 1$ with $1 \%$ Triton X-100, 2 mM EDTA, $50 \mathrm{mM} \mathrm{NaCl}, 20 \mathrm{mM}$ Tris-HCl, $\mathrm{pH} 8.1$ containing the same amounts of protease inhibitors. Samples were precleared for $1 \mathrm{~h}$ at $4^{\circ} \mathrm{C}$ with $20 \mu \mathrm{l}$ of protein-A-agarose (Sigma). Immunoprecipitation was performed overnight at $4^{\circ} \mathrm{C}$ with the addition of $5 \mu \mathrm{g}$ normal rabbit serum IgG (Santa Cruz Biotechnology sc-2027), rabbit anti-AR H-280 (Santa Cruz Biotechnology sc-13062) or CKBBP2/CRIF1 antibody. Samples were incubated with $20 \mu \mathrm{l}$ of protein-A agarose for $3 \mathrm{~h}$ and protein-A agarose pellets washed sequentially with $1 \mathrm{ml}$ each of low salt buffer (0.1\% SDS, $1 \%$ Triton X-100, 2 mM EDTA, 20 mM Tris-HCl, pH 8.1 and $150 \mathrm{mM} \mathrm{NaCl})$, high salt buffer (0.1\% SDS, $1 \%$ Triton X-100, 2 mM EDTA, 20 $\mathrm{mM}$ Tris-HCl, $\mathrm{pH} 8.1$ and $500 \mathrm{mM} \mathrm{NaCl}), \mathrm{LiCl}$ buffer $(0.25 \mathrm{M} \mathrm{LiCl}, 1 \%$ Triton X-100, 1 mM EDTA, $10 \mathrm{mM}$ Tris-HCl, $\mathrm{pH} 8.1$ and $1 \%$ sodium deoxycholate) and $2 \times 1 \mathrm{ml} \mathrm{TE}$ buffer (10 mM Tris-HCl, pH 8.1, 1 mM EDTA). Immunoprecipitated DNA was eluted in $50 \mu \mathrm{l}$ of $1 \%$ SDS, $0.1 \mathrm{M} \mathrm{NaHCO}_{3} 3$ times at $25^{\circ} \mathrm{C}$ for $15 \mathrm{~min}$ each. The resulting DNA was decrosslinked by adding $6 \mu$ of $5 \mathrm{M} \mathrm{NaCl}$, incubated at $65^{\circ} \mathrm{C}$ overnight, followed by $45^{\circ} \mathrm{C}$ incubation with the addition of $2.4 \mu \mathrm{l}$ of $0.5 \mathrm{M}$ EDTA, $4.8 \mu \mathrm{l}$ of $2 \mathrm{M}$ Tris-HCl, $\mathrm{pH} 6.5,2 \mu \mathrm{l}$ of $10 \mathrm{mg} / \mathrm{ml}$ proteinase $\mathrm{K}$ and $2 \mu \mathrm{l}$ of $10 \mathrm{mg} / \mathrm{ml} \mathrm{RNase}$ A for $1 \mathrm{~h}$. DNA was purified and PCR performed in $10 \mu \mathrm{l}$ reactions using SYBR green and PSA gene upstream enhancer primers 5'-GGGACAACTTGCAAACCTG- $3^{\prime}$ and 5'-GTATCTGTGTGTCTTCTGAGC-3' at $95^{\circ} \mathrm{C}$ for $20 \mathrm{~min}, 40 \mathrm{cycles}$ of $95^{\circ} \mathrm{C}$ for $30 \mathrm{sec}, 57^{\circ} \mathrm{C}$ for $30 \mathrm{sec}, 72^{\circ} \mathrm{C}$ for $45 \mathrm{sec}$ to amplify a $285 \mathrm{bp}$ fragment from the -4234 to $-39505^{\prime}$-flanking region.

\subsection{DNA binding assay}

COS cells $\left(1.8 \times 10^{6} / 10 \mathrm{~cm}\right.$ dish) transfected with $5 \mu \mathrm{g}$ empty vector control (pSG-FLAG), pSGFLAG-AR or CK $\beta B P 2 / C R I F 1$ in the presence of $10 \mathrm{nM}$ DHT were harvested in PBS and lysed with $250 \mu \mathrm{l}$ buffer containing $1 \%$ Triton X-100, $1 \%$ sodium deoxycholate, $0.15 \mathrm{M}$ $\mathrm{NaCl}, 0.1 \%$ SDS, $50 \mathrm{mM}$ NaF, $2 \mathrm{mM}$ sodium vanadate, $2 \mathrm{mM}$ EDTA, $50 \mathrm{mM}$ Tris- $\mathrm{HCl}, \mathrm{pH}$ 7.6 plus $1 \mathrm{mM}$ phenylmethylsulfonyl fluoride, $1 \mathrm{mM}$ dithiothreitol and complete protease inhibitor cocktail (Roche Applied Science). The same PSA upstream enhancer DNA amplified in the ChIP assay ( $5 \mu \mathrm{l}$ of $10 \mu \mathrm{lM}$ stock) was added to $50 \mu \mathrm{l} \mathrm{COS}$ cell protein extract and $90 \mu \mathrm{l}$ DNA binding buffer (10 mM Tris, pH 7.5, $25 \mathrm{mM} \mathrm{KCl}, 0.1 \mathrm{mM}$ EDTA, 1 mM DTT, $10 \%$ glycerol) with $1 \mathrm{mM} \mathrm{ZnSO}_{4}$, incubated for $3 \mathrm{~h}$ at $4^{\circ} \mathrm{C}, 25 \mu$ of M2-FLAG antibody-agarose beads added and incubation continued overnight at $4^{\circ} \mathrm{C}$. The next day, agarose beads were washed 3 times with $1 \mathrm{ml}$ DNA binding buffer with $\mathrm{ZnSO}_{4}$. DNA binding buffer $(100 \mu \mathrm{l})$ containing RNase and proteinase $\mathrm{K}$ was added to the beads and incubated at $65^{\circ} \mathrm{C}$ for $1 \mathrm{~h}$. The mixture was phenol extracted, ethanol precipitated, dissolved in $10 \mu \mathrm{l}$ of $\mathrm{H}_{2} \mathrm{O}$ and separated in a $1 \%$ agarose gel. The area of gel corresponding to the PSA 
upstream enhancer DNA was cut out, DNA was eluted and used for RT-PCR. The amount of RT-PCR amplified DNA was calculated based on a PSA standard curve using genomic DNA. Fold binding was calculated against empty vector control (pSGFLAG) set to 1.

\section{9 siRNA transfection}

CK $\beta$ BP2/CRIF1 siRNAs were obtained from Dharmacon, Chicago, IL ( $5^{\prime}-3^{\prime}$ sense sequences siRNA1 ${ }^{197}$ CUAAGCAGUUCGCGCGUUAUU, siRNA2 ${ }^{264}$ GAGCUGGAGGCCGAAGAACUU). siRNAs were transfected into COS cells along with pSGFLAG-CK $\beta B$ P2/CRIF1 or pSGFLAG empty vector using Lipofectamine 2000 (Invitrogen) according to the manufacture's instructions. COS cells were plated in $6 \mathrm{~cm}$ dishes at $3 \times 10^{5} /$ dish (50-60\% confluent) and cultured in DMEM-H without the addition of antibiotics. Lipofectamine diluted 1:10 in Opti-MEM medium was incubated at room temperature for $5 \mathrm{~min}$ and added to Eppendorf tubes containing siRNA and vector DNA, incubated an additional $20 \mathrm{~min}$ at room temperature and mixed before adding to the cells. COS cells were incubated for $48 \mathrm{~h}$ at $37^{\circ} \mathrm{C}$ and harvested in PBS. CV1 cells plated in $6 \mathrm{~cm}$ dishes at $4.5 \times 10^{5}$ cells/dish and cultured in DMEM-H. CWR-R1 cells in 6 well dishes at 4 $\times 10^{5}$ cells/well were cultured in Richter's medium transfected with Lipofectamine as above.

\subsection{Immunoblots}

Antibodies were raised in rabbits with CK $\beta B P 2 / C R I F 1$ peptide ${ }^{144}$ CEKAQADKERRARLQA $^{158}$ (Pocono Rabbit Farm \& Laboratory, Inc. PA) and purified using peptide antigen affinity chromatography. For antibody assay, western blots were performed using protein extracts from COS cells transfected with pSGFLAG or pSGFLAG-CKßBP2/CRIF1.

The small repressor CK $\beta \mathrm{BP} 2 / \mathrm{CRIF} 1$ protein fragment amino acids158-206 was expressed in COS cells and identified by chromatography on a $4-20 \%$ gradient gel.

\subsection{Immunohistochemistry}

Surgical specimens of prostate were collected according to NIH guidelines with approval by the IRB of Roswell Park Cancer Institute and the University of North Carolina School of Medicine at Chapel Hill. BPH cores were taken from radical prostatectomy specimens at sites away from the cancer. Tissue microarray (Titus et al., 2005) was performed as follows: formalin-fixed, paraffin-embedded tissue microarray sections were incubated at $70^{\circ} \mathrm{C}$ for 15 min, deparaffinized in toluene and rehydrated through graded alcohols to phosphate buffered saline. Endogenous peroxidase was blocked using $5 \% \mathrm{H}_{2} \mathrm{O}_{2}$ in $83 \%$ methanol for $30 \mathrm{~min}$ at room temperature. For antigen retrieval, slides were placed in $0.01 \mathrm{M}$ sodium citrate, $0.01 \mathrm{M}$ critic acid, $\mathrm{pH} 6.0$ for $15 \mathrm{~min}$ in a microwave on high setting followed by $15 \mathrm{~min}$ cool down incubation in the citrate solution (Balaton et al., 1993). Sections were blocked with $1.5 \%$ normal goat serum (for anti-CKßBP2/CRIF1) or rabbit serum (for anti-STAT3) for $20 \mathrm{~min}$ and incubated overnight at $4^{\circ} \mathrm{C}$ with anti-CK $\beta$ BP2/CRIF1 (1:100 dilution) or anti-STAT3 ab30646 antibodies (1:100 dilution, Abcam). Slides were blocked in normal serum for 10 $\mathrm{min}$ and incubated at room temperature for $30 \mathrm{~min}$ with biotinylated anti-rabbit IgG (1:200 dilution) (Vector Labs, Burlingame, CA) followed by a $30 \mathrm{~min}$ incubation at room temperature with the Elite Avidin DH-biotinylated horseradish peroxidase $\mathrm{H}$ complex (1:50 dilution) (Vector Labs). Sections were incubated for 10 min with 3, 3'diamino-benzidine (DAB Peroxidase Substrate Kit SK-4100, Vector Labs) and counterstained with Gill's hematoxylin (Protocol Hematoxylin Gill-3X, Fisher Scientific). APERIO Imagescope software was used to capture and store the images. Defective cores with tissue damage were excluded from scoring for CK $\beta$ BP2/CRIF1 and STAT3 staining. The analysis shown in Fig. 8 included 25 cores each of $\mathrm{BPH}$, androgen-dependent and castration-recurrent prostate cancer. 


\subsection{Realtime RT-PCR}

RNA was extracted using Trizol (Qiagen) according to manufacturer's recommendations. RNA $(2 \mu \mathrm{g})$ was reverse-transcribed using SuperScript II Reverse Transcriptase (Invitrogen). RT-PCR using QuauntiTech SYBR Green (Qiagen) was performed in a Roche Life Cycler using $100 \mathrm{ng}$ cDNA. Gene expression calculation was based on the standard curve. Relative expression was defined as sample mRNA expression divided by internal control. Standard curves for the internal control gene cyclophilin (peptidylprolyl isomerase A, PPIA) or CK $\beta B P 2 / C R I F 1$ were prepared in a RT-PCR assay using serial dilutions of the cDNA. Primers for CK $\beta$ BP2/CRIF1 were 5'-GGACCCCGCACAGCCAAGATGG-3' and 5'-GAGGCTGCTGGGTCTTGAGC-3', for PPIA 5'-GGGCCGCGTCTCCTTTGAGC-3' and 5'-CATTCCTGGACCCAAAGCGCTC-3'.

\subsection{Statistical Analysis}

Analyses were performed using Student's t-test and Microsoft Excel Tools. Error bars represent \pm SEM. Differences were considered significant at $p<0.05$.

\section{Results}

\subsection{CKßBP2/CRIF1 interacts with ligand-activated AR in yeast}

Yeast two hybrid screening of a HeLa cell cDNA library was performed using as bait human AR-481-919 carboxyl-terminal fragment that includes a portion of the $\mathrm{N}$-terminal domain and DNA and ligand binding domains. Approximately $6 \times 10^{5}$ yeast library colonies were screened and 6 colonies were positive in the $\beta$ galactosidase assay. One clone was protein

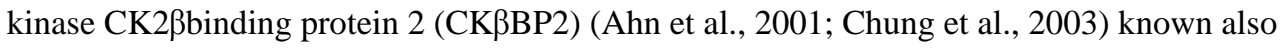
as a GADD $45 \gamma$ interacting protein, CR6-interacting factor 1 (CRIF1) and referred to here as CK $\beta$ BP2/CRIF1.

The interaction of CK $\beta$ BP2/CRIF1 with AR-481-919 was analyzed using a yeast liquid $\beta$ galactosidase assay. Yeast strain Y190 transformed with pBDGAL-CAM-AR-481-919 and pGADGH-CKßBP2/CRIF1 or pGADGH empty vector control were grown in selective medium with or without androgen. There was a slight increase in $\beta$ galactosidase activity over the control background in the absence of CK $\beta B P 2 / C R I F 1$, however activity increased 8 -fold over background in the presence of DHT when both CK $\beta B P 2 / C R I F 1$ and AR were present (Fig. S1A). This was 4-fold greater than the increase $\beta$ galactosidase activity in the absence of CK $\beta$ BP2/CRIF1, indicating a DHT-dependent interaction of CK $\beta B P 2 / C R I F 1$ and AR. The HeLa cell cDNA clone lacks the first 6 amino acid residues MAASVR compared to the published sequence of CRIF1 (Ahn et al., 2001) and there is a single nucleotide (C to T) difference from the published sequence changing Arg 187 to Cys (Fig. S1B).

\subsection{CKßBP2/CRIF1 over-expressed in COS cells interacts with AR in the nucleus and inhibits AR transcriptional activation}

Immunostaining for AR and CK $\beta$ BP2/CRIF1 over-expressed in COS cells showed nuclear localization in the presence of DHT (Fig. 1A). An androgen-dependent interaction between CKßBP2/CRIF1 and AR was suggested by co-immunoprecipitation in COS cells (Fig. 1B). Immunoprecipitation with FLAG antibody showed AR bound to FLAG-CK $\beta B P 2 /$ CRIF1-7-222 and to FLAG-CK $\beta B P 2 / C R I F 1-1-222$ in the presence of DHT, with no detectable interaction in the absence of DHT. The results indicate that CK $\beta B P 2 / C R I F 1$ binds to the DHT-activated AR.

Chromatin immunoprecipitation showed that following exposure to R1881, AR and $\mathrm{CK} \beta \mathrm{BP} 2 / \mathrm{CRIF} 1$ located to chromatin at 3 and $6 \mathrm{~h}$ in the region of the PSA gene upstream enhancer (Fig. 1C). AR bound the PSA gene upstream enhancer DNA while CK $\beta B P 2 /$ 
CRIF1 did not (Fig. 1D), suggesting CKßBP2/CRIF1 was bound to AR at this chromatin site.

\subsection{Repressor effect of CK $\beta B P 2 / C R I F 1$ on DHT-dependent AR transcriptional activity}

CV1 cells were transfected with MMTV-Luc and full-length AR together with pSGFLAGCKßBP2/CRIF1 or pSGFLAG vector control (Fig. 2). Luciferase activity with pSGFLAGCK $\beta$ BP2/CRIF1 $(0.1$ or $0.5 \mu \mathrm{g})$ was decreased compared to the pSGFLAG empty vector control. The results suggested a repressor effect of CK $\beta B$ P2/CRIF1 on AR transactivation. In similar assays, CK $\beta B P 2 / C R I F 1$ inhibited transcriptional activity of the human progesterone receptor-B but not the glucocorticoid receptor (Fig. S2).

\subsection{CKßBP2/CRIF1 inhibits the AR N/C interaction and binding of the $\mathrm{p} 160$ coactivator TIF2 to the AR C-terminal region}

We used a mammalian two-hybrid assay to test the influence of CKBBP2/CRIF1 on AR Nterminal region binding to the AR C-terminal region (AR N/C interaction) (He et al., 2000, 2001, 2004). HeLa cells were transfected with a 5 XGal4Luc3 reporter gene together with GAL-AR-624-919 (AR C-terminal region linked to the GAL4 DNA binding domain) and VP-AR-1-660 (AR N-terminal and DNA binding domain linked to the VP16 activation domain). A strong DHT-dependent AR N/C interaction between VP-AR-1-660 and GALAR-624-919 was inhibited by CKßBP2/CRIF1 compared to the pSGFLAG control (Fig. 3A, left).

A similar experiment indicated that CK $\beta B P 2 / C R I F 1$ inhibited binding of the p160 coactivator TIF2 to the AR C-terminal region. With co-transfection of control pSGFLAG, VP-TIF2.1 interacted strongly with the C-terminal Gal-AR-624-919, but this interaction was reduced markedly in the presence of CK $\beta \mathrm{BP} 2 / \mathrm{CRIF} 1$ (Fig. 3A, right). Thus, in addition to its inhibitory effect on the AR N/C interaction, CK $\beta B P 2 / C R I F 1$ interfered with the binding of TIF2 to the AR C-terminal region.

CK $\beta$ BP2/CRIF1 inhibition of AR transcriptional activation was overcome by an increase in TIF2 (Fig. 3B). CV1 cells were cotransfected with pSG-AR and the MMTV-Luc reporter vector together with $0.5 \mu \mathrm{g}$ pSGFLAG control or $\mathrm{pSG}-\mathrm{CK} \beta \mathrm{BP} 2 / \mathrm{CRIF} 1$ expression vector, each with either pSGTIF2 ( 0.1 or $0.5 \mu \mathrm{g})$ or the same amount of pSGFLAG empty vector control. In the presence of control, TIF2 increased DHT-dependent luciferase activity (Fig. 3B, left). When cells were cotransfected with CK $\beta$ BP2/CRIF1 $(0.5 \mu \mathrm{g})$ the increase with TIF2 $(0.1 \mu \mathrm{g})$ was inhibited. However, the increase with TIF2 $(0.5 \mu \mathrm{g})$ was not inhibited by CKßBP2/CRIF1 $(0.5 \mu \mathrm{g})$ (Fig. 3B, right) consistent with competitive inhibition.

\subsection{CKßBP2/CRIF1 interacts preferentially with the AR C-terminal region in cell-free binding assays}

Binding of $\left[{ }^{35} \mathrm{~S}\right] \mathrm{CK} \beta \mathrm{BP} 2 / \mathrm{CRIF} 1-7-222$ to GST-AR N-terminal, DNA binding domain or Cterminal ligand binding domain was compared in a glutathione-Sepharose affinity matrix assay. CK $\beta$ BP2/CRIF1 binding to the AR ligand binding domain (AR amino acid residues 624-919) was evident (Fig. 3C), whereas binding to the N-terminal (1-503) and DNA binding domain (544-634) regions of AR was less and revealed only by longer exposure of the x-ray film (not shown). In a similar assay, there was no direct interaction between CKßBP2/CRIF1 and TIF2 (data not shown).

Binding of CK $\beta \mathrm{BP} 2 / \mathrm{CRIF} 1$ to the $\mathrm{C}$-terminal region of $\mathrm{AR}$ and the ability of TIF2 to overcome CK $\beta B P 2 / C R I F 1$ inhibition of AR transcriptional activity suggested the CK $\beta B P 2 /$ CRIF1 and TIF2 interaction sites in the AR C-terminal region overlap. It is known that an LXXLL motif in TIF2 interacts with AR activation function 2 (AF2) in the AR C-terminal 
region and that TIF2 can compete with the AR N-terminal FXXLF motif binding to AF2 (He et al., 1999, 2001, 2004).

\subsection{CKßBP2/CRIF1 inhibits constitutive transcriptional activity of AR N-terminal-DNA binding domain}

An influence of CKBBP2/CRIF1 on the AR N-terminal activation function was explored using the constitutively active AR-1-660 that includes the AR N-terminal region and DNA binding domain. When CK $\beta \mathrm{BP} 2 / \mathrm{CRIF} 1$ was co-transfected in CV1 cells with pCMVAR-1-660 and MMTV-Luc, AR-1-660 induced activity was inhibited compared to the pSGFLAG control vector (Fig. 4A).

Melanoma antigen-A11 (MAGE-A11) is an AR coregulator that binds the AR N-terminal FXXLF motif region and increases AR transcriptional activity by stabilizing AR and recruiting TIF2 and p300 (Bai et al., 2005, 2008; Askew et al., 2009, 2010). To further characterize the influence of CK $\beta B P 2 / C R I F 1$ on the AR N-terminal activation function, CV1 cells were transfected with pCMV-AR-1-660 and PSA-Enh-Luc with and without pSG-MAGE (Fig. 4B). AR-1-660 induced luciferase activity was increased by MAGE-A11 and inhibited by CK $\beta$ BP2/CRIF1. The results were consistent with an interaction of CK $\beta$ BP2/CRIF1 with the AR N-terminal region. CK $\beta B P 2 / C R I F 1$ may interfere with binding of MAGE-A11, TIF2 or p300 to the AR N-terminal region.

\subsection{C-terminal region of CKßBP2/CRIF1 is sufficient for inhibition of AR transcriptional activation}

The AR inhibitory region of CK $\beta B P 2 / C R I F 1$ was investigated using peptide of CK $\beta B P 2 /$ CRIF1 (Fig. 5). CKßBP2/CRIF1-158-206 inhibition of DHT-dependent AR transcriptional activity was stronger than CK $\beta B P 2 / C R I F 1-7-157$ and similar to that of the nearly full-length CKßBP2/CRIF1-7-222 (Fig. 5A). Since CKßBP2/CRIF1-158-206 contains a nuclear translocation-like sequence, an explanation for its stronger inhibitory activity might be greater availability to AR in nuclei. However, CK $\beta B P 2 / C R I F 1$ fragments 7-157 and 158-206 were nuclear in COS cell expression experiments (results not shown) and they coimmunoprecipitated with full-length AR in a DHT-dependent manner (Fig. 5B). The CKßBP2/CRIF1-158-206 peptide was identified by separation on a 4-20\% SDS-glycine gradient gel (Fig. S4).

CKßBP2/CRIF1-158-206 contains a predicted ahelical motif sequence ${ }^{175} \mathrm{FQELL}^{179}$ similar to the AR N-terminal FXXLF motif that binds AR AF2 (He et al., 2004, 2000). Mutation of the FXXLF motif to ${ }^{175} \mathrm{FQEAA}{ }^{179} \mathrm{i}$ in the AR N-terminus abolished its ability to bind AR AF2 (He et al. 2000). However, CK $\beta B P 2 / C R I F 1-7-222$ containing the mutant sequence ${ }^{175} \mathrm{FQEAA}{ }^{179}$ (FXXAA) retained the ability to inhibit AR transcriptional activity (Fig. 5A) and to bind AR in a DHT-dependent manner (Fig. 5C), suggesting the ${ }^{175}$ FQELL ${ }^{179}$ motif was not required for the inhibitory interaction of CK $\beta B P 2 /$ CRIF1-7-222 with AR.

\section{8 siRNA knockdown of endogenous CKßBP2/CRIF1 in CWR-R1 human prostate cancer cells increases AR transcriptional activity}

CWR-R1 cells express AR at levels sufficient for reporter gene analysis of DHT-dependent transcription. CK $\beta$ BP2/CRIF1 inhibited endogenous AR activity in transient transfection assays in CWR-R1 cells transfected with MMTV-Luc together with pSGFLAG-CK $\beta B P 2 /$ CRIF1-2-222 or -7-222 (Fig. 6A).

CWR-R1 cells expressed CK $\beta B P 2 / C R I F 1$ protein by immunostaining (not shown). siRNA knockdown indicated a repressor influence of endogenous CKRBP2/CRIF1 on AR 
transcriptional activity. In initial experiments, CK $\beta$ BP2/CRIF1 siRNAs were tested in COS cells for their ability to inhibit overexpression of recombinant CK $\beta B P 2 / C R I F 1$. siRNA1 eliminated detectable CK $\beta \mathrm{BP} 2 / \mathrm{CRIF} 1$ protein, whereas siRNA2 reduced it by only about $20 \%$ of the control (Fig. 6B). The siRNAs were also tested in DHT-dependent transcription assays using CV-1 cells cotransfected with AR and MMTV-Luc with and without siRNA. In this assay, CK $\beta B P 2 / C R I F 1$ inhibition of DHT and AR-stimulated luciferase activity was prevented by siRNA1 but not by siRNA2 (Fig. 6C).

Knockdown of endogenous CK $\beta$ BP2/CRIF1 in CWR-R1 cells transfected with MMTV-Luc was performed with increasing amounts of siRNA-1 or 2 in the presence and absence of DHT. At each siRNA concentration, DHT-stimulated luciferase activity was $2-3$ fold higher with siRNA-1 compared to siRNA-2 (Fig. 6D). The results are consistent with a repressor effect of endogenous CK $\beta B P 2 / C R I F 1$ on AR transcriptional activity in CWR-R1 cells. Repression of AR by endogenous CK $\beta B P 2 / C R I F 1$ was released by siRNA1 more than by SiRNA2.

\subsection{CKßBP2/CRIF1 mRNA expression in human prostate cancer}

$\mathrm{AR}$ is expressed in stroma and epithelium of benign prostatic hyperplasia (BPH) and prostate cancer. Levels of CK $\beta$ BP2/CRIF1 mRNA did not differ significantly in clinical specimens of BPH, androgen-dependent and castration-recurrent prostate cancer tissue (Fig. 7).

\subsection{CKßBP2/CRIF1 protein is expressed together with STAT3 in stroma and epithelium of prostate cancer}

Because of the reported interaction and transcriptional coactivator effect of CK $\beta$ BP2/CRIF1 on STAT3 (Kwon et al., 2008), we confirmed the direct interaction of CK $\beta B P 2 / C R I F 1$ and STAT3 (Fig. S3) and performed immunostaining of CK $\beta B P 2 / C R I F 1$ and STAT3 in adjacent microtome thin sections of a prostate cancer tissue microarray to determine whether the two proteins are localized in the same cells. Proteins were analyzed by immunostaining 25 cores each of human BPH, androgen-dependent and castration-recurrent prostate cancer (Fig. 8). Staining of CK $\beta B P 2 / C R I F 1$ in BPH was mainly in stromal cells with weaker staining of epithelial cells. CK $\beta B P 2 / C R I F 1$ staining was strongest in fibromuscular cells of stroma. In androgen-dependent prostate cancer, CK $\beta$ BP2/CRIF1 staining remained similar in stroma but was increased in epithelial cells compared to BPH and was mainly in the cytoplasm of epithelial cells (Fig. 8). In castration-recurrent prostate cancer, CK $\beta$ BP2/CRIF1 staining of epithelium decreased compared to androgen-dependent prostate cancer (Fig. 8). In a subset of cores (20\%) CK $\beta$ BP2/CRIF1 staining was not detected in epithelial cells of castrationrecurrent prostate cancer. Boundaries between epithelial and stromal cells were often obscure in castration recurrent prostate cancer.

STAT3 immunostaining was nuclear and cytoplasmic throughout the glandular epithelium and stroma. STAT3 protein was present wherever CK $\beta$ BP2/CRIF1 protein was expressed in BPH and prostate cancer (Fig. 8). STAT3 is activated in prostate cancer (Dhir et al., 2002), can bind AR (Matsuda et al., 2001) and stimulates the growth of prostate cancer cells (Ni et al., 2000).

\section{Discussion}

CKßBP2/CRIF1 functioned as an AR corepressor by binding the AR C-terminal region and inhibiting the AR N/C interaction, wherein the FXXLF ahelical motif $\left({ }^{23} \mathrm{FQNLF}^{27}\right)$ in the $\mathrm{AR} N$-terminus binds the hydrophobic AF2 region in the C-terminus. CK $\beta B P 2 / C R I F 1$ binding to the $\mathrm{C}$-terminal region of $\mathrm{AR}$ also competed for binding of the $\mathrm{p} 160$ coactivator 
TIF2 to the AR C-terminal region, an interaction involving a TIF2 ahelical LXXLL motif (He et al., 2001, 2004). CK $\beta B P 2 / C R I F 1$ did not bind TIF2, but inhibited TIF2 binding to AR. However, higher amounts of TIF2 could overcome CK $\beta B P 2 / C R I F 1$ inhibition of AR transcriptional activity in CV1 cells.

Our evidence that CK $\beta B P 2 / C R I F 1$ interacts directly with the AR C-terminus differs from another study (Suh JH et al., 2008) where interaction with the AR N-terminus in a pull-down assay was stronger than with the AR C-terminus. The difference may be due to the androgen-dependent nature of CK $\beta \mathrm{BP} 2 / \mathrm{CRIF} 1$ binding to the AR ligand-binding domain. However, we cannot rule out that the hinge region 33 amino acids 624-656, present in our construct but not that of Shu J.H. et al. 2008, played a role in the binding difference with Shu J.H. et al.

We found that CK $\beta$ BP2/CRIF1 also inhibited the constitutive transcriptional activity of AR-1-660, an AR N-terminal and DNA binding domain fragment, alone or in the presence of MAGE-A11. This inhibition of transcriptional activity may reflect an interaction of CKßBP2/CRIF1 with the AR N-terminal region, although this appeared weaker than the androgen-dependent binding of CK $\beta B P 2 / C R I F 1$ to the AR C-terminal domain in affinity matrix assays.

MAGE-A11 is an AR coregulator that interacts with the AR N-terminal FXXLF motif region. Binding of MAGE-A11 to the FXXLF motif can compete with the AR N/C interaction between the AR FXXLF motif and AF2 in the AR ligand binding domain (Bai et al., 2005; Bai and Wilson, 2008). MAGE-A11 increases AR transcriptional activity by binding and promoting AR complexes with TIF2 (Askew et al., 2009) and p300 (Askew et al., 2010). p160 coactivators such as TIF2 bind the AR N-terminal region (Bevan et al., 1999). However, an intermediary protein may modulate these p160 interactions with the unstructured AR N-terminus (Lavery and McEwan, 2008a,b). In prostate cancer cells with higher MAGE-A11 protein expression, TIF2 may be linked to the AR N-terminus in part through its binding to MAGE-A11 (Askew et al., 2009). This suggested that CK $\beta B P 2 /$ CRIF1 might also inhibit AR action by interfering with coregulators that bind the AR Nterminal region.

The AR N/C interaction brings together the unstructured N-terminal region with the highly structured $\mathrm{C}$-terminal region and has a stabilizing effect on AR by slowing the dissociation rate of bound DHT (He et al., 2002, 2004, 2006). The AR N/C interaction may influence coactivator interacting surfaces in AF1 in the N-terminal region (Lavery and McEwan, 2008a,b). Several lines of evidence indicate that the AR N/C interaction has an essential role in transcriptional activity ( $\mathrm{Li}$ et al., 2006). AR mutations that interfere with the N/C interaction or its effects on AR coregulator interactions are associated with partial androgen insensitivity in humans (Quigley et al., 2004; Lagarde et al., 2012). Moreover, inhibition of the AR N/C interaction by other AR corepressors (Burd et al., 2006) may reflect the importance of this domain interaction in AR functional activity.

Other AR corepressors that inhibit the AR N/C interaction are cyclin D1 (Burd et al., 2005, 2006), SMRT (Dotzlaw et al., 2002; Liao et al., 2003) and NCoR (Cheng et al., 2002;

Berrevoets et al., 2004; Wu et al., 2006; Hodgson et al., 2008) that interacts with both $\mathrm{N}$ and $\mathrm{C}$ terminal regions of AR. NCoR inhibition of AR resembles that of CK $\beta B P 2 / C R I F 1$ in that its AR inhibitory effect in the presence of R1881 can be reversed by TIF2 (Berrevoets et al., 2004), suggesting competition between NCoR and TIF2 for binding sites on ligand activated AR. Binding of NCoR to AR can be increased by antiandrogens (Dotzlaw et al., 2002; Berrevoets et al., 2004; Wu et al., 2006; Hodgson et al., 2008). 
In the PPC-1 cell line derived from a primary human prostate cancer, the histone deacetylase inhibitor trichostatin A abolished the repressor activity of CK $\beta B P 2 / C R I F 1$ on AR transcriptional activity and this effect was dependent on histone deacetylase-4 (HDAC-4) activity (Suh et al., 2008). HDAC-4 was present in nuclei of castration-recurrent prostate cancer (Halkidou et al., 2004). Class 1 HDACs 1-3 are also expressed in prostate cancers (Witt et al., 2009). We found a variety of HDAC mRNAs in a small group of prostate cancers including HDAC-4 (data not shown). A number of AR corepressors recruit HDACs (Burd et al., 2006; Gross et al., 2004) and may form complexes that control HDAC turnover (Guo et al., 2012).

The AR inhibitory activity of CK $\beta B P 2 / C R I F 1$ in $\mathrm{CV} 1$ cells resided mainly in its C-terminal region. Similarly, C-terminal CK $\beta B P 2 / C R I F 1-99-222$ exhibited stronger AR binding than the $\mathrm{N}$-terminal region in a yeast interaction assay and had stronger AR repressor activity in HEK-293 cells (Suh et al., 2008). We identified a 49 amino acid CKßBP2/CRIF1-158-206 fragment that retained AR binding activity and strong inhibition of AR transcriptional activity. This fragment contains a potential coiled-coil region of a-helices and includes an FXXLL motif similar to the AR N-terminal FXXLF motif, suggesting that like the AR FXXLF motif, it might confer binding to AR AF2. However, mutation of this motif to FXXAA in CKßBP2/CRIF1 7-222 did not alter binding to full-length AR and caused only slight inhibition of AR transcriptional activity compared to the parent fragment containing FXXLL. In murine C2C12 skeletal muscle cells, C-terminal CKßBP2/CRIF1-99-222 was a stronger inhibitor of Nurr-77 transactivation than was the N-terminal region of CK $\beta B P 2 /$ CRIF1 (Park et al., 2005).

CKßBP2/CRIF1 was reported to enhance the actions of GADD45 (Chung et al., 2003), a p53 induced DNA damage and cell stress response protein (Carrier et al., 1999; Liebermann and Hoffman, 2008). As participants in the cell response to DNA damage, CK $\beta$ BP2/CRIF1 and other corepressors, forkhead transcription factor FoxO1 (Ma et al., 2009) and checkpoint protein hRAD9 (Wang et al., 2004), also inhibited the AR N/C interaction. FoxO1 binding to the AR N-terminal region interfered with the AR N/C interaction, blocked $\mathrm{N}$-terminal binding of a p160 coactivator and inhibited AR transcriptional activation. AKT phosphorylation of FoxO1 prevented its AR corepressor activity and PTEN suppressed this action of AKT. FoxO1 repressor activity was also inhibited by CDK2 activity, and when CDK2 activity was abolished in response to DNA damage, FoxO1 was activated (Huang and Tindall, 2007). In this connection, CKßBP2/CRIF1 was also reported to inhibit CDK2 activity (Chung et al., 2003) and thereby may contribute to an increase in FoxO1 corepressor activity. hRAD9 is a member of the RAD family of checkpoint proteins and a multifunctional sensor and regulator of the cellular response to DNA damage involved in DNA repair, checkpoint activation, cell cycle regulation and apoptosis signaling (Ishikawa et al., 2007). An FXXLF motif in the hRAD9 C-terminal region interacted with the AR Cterminal region, presumably $\mathrm{AF} 2$, inhibited the $\mathrm{AR} N / \mathrm{C}$ interaction and $\mathrm{AR}$ transcriptional activation (Wang et al., 2004).

Loss of CK $\beta$ BP2/CRIF1 may have a growth stimulating effect in some cells as a consequence of removing growth inhibition by CK $\beta B P 2 / C R I F 1$ unrelated to AR. For example, NAC-1, a BTB/POZ protein, repressed transcription of the CKßBP2/CRIF1 gene. In HeLa cells, the increase in CK $\beta B P 2 / C R I F 1$ expression resulting from silencing NAC-1 was associated with growth inhibition in cell culture and xenographs (Nakayama et al., 2006). Since HeLa cells contain low levels of AR and their growth is not stimulated by androgen, inhibition of growth associated with an increase in CK $\beta B P 2 / C R I F 1$ protein may have resulted from tumor suppressor effects of CK $\beta B P 2 / C R I F 1$ similar to those of GADD45y Similarly, castration recurrent prostate cancer epithelial cells with a lower 
amount of CK $\beta B P 2 / C R I F 1$ protein may have a selective growth advantage due to increased transcriptional activity of AR.

Recent studies suggest that CRIF1 has a role in oxidative phosphorylation through the integration of polypeptides into the mitochondrial membrane (Kim et al., 20121; Shin et al. 2013) and that is part of the mammalian ribosome (Koc et al. 2013). In addition, CRIF1 has a role in oxidative phosphorylation in mouse adipose tissue (Ryu et al. 2013). Other evidence supports multiple functions of CK $\beta$ BP2/CRIF1 in transcription factor regulation. CKßBP2/CRIF1 is a coactivator of ELF3 (E74-like factor 3) (Kwon et al., 2009) and STAT3 (Kwon et al., 2008). CK $\beta$ BP2/CRIF1 down-regulates the transcription factor NRF2 by promoting ubiquitination and degradation (Kang et al., 2010). In our studies, CK $\beta$ BP2/ CRIF1 was an activator of the cytomegalovirus promoter but not the simian virus 40 promoter (Fig. S5).

Multifunctional effects of CK $\beta B P 2 / C R I F 1$ may regulate actions of AR, STAT3 and other transcription factors in prostate reactive stroma and in epithelium that control vascularization and growth of prostate cancer (Berry et al., 2008; Yang et al., 2005; Montecinos et al., 2012).

\section{Supplementary Material}

Refer to Web version on PubMed Central for supplementary material.

\section{Acknowledgments}

John T. Minges and Amanda J. Blackwelder provided valuable technical assistance. The work was supported in whole or part by National Institutes of Health grants CA77739 (FSF, JLM, GJS, EMW), HD16910 and United States Army Material Command DAMD 17-02-1-0110 (EMW).

\section{References}

Agoulnik IU, Weigel NL. Androgen receptor action in hormone-dependent and recurrent prostate cancer. J Cell Biochem. 2006; 99:362-372. [PubMed: 16619264]

Ahn BH, Kim TH, Bae YS. Mapping of the interaction domain of the protein kinase CKII beta subunit with target proteins. Mol Cells. 2001; 12:158-163. [PubMed: 11710515]

Askew EB, Bai S, Hnat AT, Minges JT, Wilson EM. Melanoma antigen gene protein-A11 (MAGE-11) F-box links the androgen receptor $\mathrm{NH}_{2}$-terminal transactivation domain to p160 coactivators. J Biol Chem. 2009; 284:34793-34808. [PubMed: 19828458]

Askew EB, Bai S, Blackwelder AJ, Wilson EM. Transcriptional synergy between melanoma antigen gene protein-A11 (MAGE-11) and p300 in androgen receptor signaling. J Biol Chem. 2010; 285:21824-21836. [PubMed: 20448036]

Bai S, He B, Wilson EM. Melanoma antigen gene protein MAGE-11 regulates androgen receptor function by modulating the interdomain interaction. Mol Cell Biol. 2005; 25:1238-1257. [PubMed: 15684378]

Bai S, Wilson EM. Epidermal-growth-factor-dependent phosphorylation and ubiquitinylation of MAGE-11 regulates its interaction with the androgen receptor. Mol Cell Biol. 2008; 28:1947-1963. [PubMed: 18212060]

Balaton AJ, Ochando F, Painchaud MH. Use of microwaves for enhancing or restoring antigen before immunohistochemical staining. Ann Pathol. 1993; 13:188-189. [PubMed: 8397545]

Battaglia S, Maguire O, Campbell MJ. Transcription factor co-repressors in cancer biology; roles and targeting. Int J Cancer. 2010; 126:2511-2519. [PubMed: 20091860]

Bevan CL, Hoare S, Claessens F, Heery DM, Parker MG. The AF1 and AF2 domains of the androgen receptor interact with distinct regions of SRC1. Mol Cell Biol. 1999; 19:8383-8392. [PubMed: 10567563] 
Berrevoets CA, Umar A, Trapman J, Brinkmann AO. Differential modulation of androgen receptor transcriptional activity by the nuclear receptor co-repressor (N-CoR). Biochem J. 2004; 379:731738. [PubMed: 14744261]

Berry PA, Maitland NJ, Collins AT. Androgen receptor signaling in prostate: effects of stromal factors on normal and cancer stem cells. Mol Cell Endocrinol. 2008; 288:30-37. [PubMed: 18403105]

Burd CJ, Petre CE, Moghadam H, Wilson EM, Knudsen KE. Cyclin D1 binding to the androgen receptor (AR) $\mathrm{NH}_{2}$-terminal domain inhibits activation function 2 association and reveals dual roles for AR corepression. Mol Endocrinol. 2005; 19:607-620. [PubMed: 15539430]

Burd CJ, Morey LM, Knudsen KE. Androgen receptor corepressors and prostate cancer. Endocr Relat Cancer. 2006; 13:979-994. [PubMed: 17158750]

Carrier F, Georgel PT, Pourquier P, Blake M, Kontny HU, Antinore MJ, Gariboldi M, Myers TG, Weinstein JN, Pommier Y, Fornace AJ. Gadd45, a p53-responsive stress protein, modifies DNA accessibility on damaged chromatin. Mol Cell Biol. 1999; 19:673-685.

Cheng S, Brzostek S, Lee SR, Hollenberg AN, Balk SP. Inhibition of the dihydrotestosterone-activated androgen receptor by nuclear receptor corepressor. Mol Endocrinol. 2002; 16:1492-1501. [PubMed: 12089345]

Chung HK, Yi YW, Jung NC, Kim D, Suh JM, Kim H, Park KC, Song JH, Kim DW, Hwang ES, Yoon SH, Bae YS, Kim JM, Bae I, Shong M. CR6-interacting factor 1 interacts with Gadd45 family proteins and modulates the cell cycle. J Biol Chem. 2003; 278:28079-28088. [PubMed: 12716909]

Dhir R, Ni Z, Lou W, DeMiguel F, Grandis JR, Gao AC. Stat3 activation in prostatic carcinomas. Prostate. 2002; 51:241-246. [PubMed: 11987152]

Dotzlaw H, Moehren U, Mink S, Cato AC, Iñiguez Lluhí JA, Baniahmad A. The amino terminus of the human AR is target for corepressor action and antihormone agonism. Mol Endocrinol. 2002; 4:661-673. [PubMed: 11923464]

Flores O, Burnstein KL. Gadd45 gamma: A new vitamin D regulated gene that is antiproliferative in prostate cancer cells. Endocrinology. 2010; 151:4654-4664. [PubMed: 20739400]

Gregory CW, Johnson RT, Mohler JL, French FS, Wilson EM. Androgen receptor stabilization in recurrent prostate cancer is associated with hypersensitivity to low androgen. Cancer Res. 2001a; 61:2892-2898. [PubMed: 11306464]

Gregory CW, He B, Johnson RT, Ford OH, Mohler JL, French FS, Wilson EM. A mechanism for androgen receptor-mediated prostate cancer recurrence after androgen deprivation therapy. Cancer Res. 2001b; 61:4315-4319. [PubMed: 11389051]

Gregory CW, Fei X, Ponguta LA, He B, Bill HM, French FS, Wilson EM. Epidermal growth factor increases coactivation of the androgen receptor in recurrent prostate cancer. J Biol Chem. 2004; 279:7119-7130. [PubMed: 14662770]

Gross M, Yang R, Top I, Gasper C, Shuai K. PIASy-mediated repression of the androgen receptor is independent of sumoylation. Oncogene. 2004; 23:3059-3066. [PubMed: 14981544]

Grossman ME, Huang H, Tindall DJ. Androgen receptor signaling in androgen refractory prostate cancer. J Nat Cancer Inst. 2001; 93:1687-1697. [PubMed: 11717329]

Guo C, Gow CH, Li Y, Gardner A, Khan S, Zhang J. Regulated clearance of histone deacetylase 3 protects independent formation of nuclear receptor corepressor complexes. J Biol Chem. 2012; 287:12111-12120. [PubMed: 22337871]

Halkidou K, Cook S, Leung HY, Neal DE, Robson CN. Nuclear accumulation of histone deacetylase 4 (HDAC4) coincides with the loss of androgen sensitivity in hormone refractory cancer of the prostate. Eur Urol. 2004; 45:382-389. [PubMed: 15036687]

He B, Kemppainen JA, Voegel JJ, Gronemeyer H, Wilson EM. Activation function 2 in the human androgen receptor ligand binding domain mediates interdomain communication with the $\mathrm{NH}_{2}$ terminal domain. J Biol Chem. 1999; 274:37219-37225. [PubMed: 10601285]

He B, Kemppainen JA, Wilson EM. FXXLF and WXXLF sequences mediate the $\mathrm{NH}_{2}$-terminal interaction with the ligand binding domain of the androgen receptor. J Biol Chem. 2000; 275:22986-22994. [PubMed: 10816582] 
He B, Bowen NT, Minges JT, Wilson EM. Androgen-induced $\mathrm{NH}_{2}$ - and $\mathrm{COOH}$-terminal interaction inhibits p160 coactivator recruitment by activation function 2. J Biol Chem. 2001; 276:4229342301. [PubMed: 11551963]

He B, Lee LW, Minges JT, Wilson EM. Dependence of selective gene activation on the androgen receptor $\mathrm{NH}_{2}$ - and $\mathrm{COOH}$-terminal interaction. J Biol Chem. 2002; 277:25631-25639. [PubMed: 12000757]

He B, Gampe RT, Kole AJ, Hnat AT, Stanley TB, An G, Stewart EL, Kalman RI, Minges JT, Wilson EM. Structural basis for androgen receptor interdomain and coactivator interactions suggests a transition in nuclear receptor activation function dominance. Mol Cell. 2004; 16:425-438. [PubMed: 15525515]

He B, Gampe RT, Hnat AT, Faggart JL, Minges JT, French FS, Wilson EM. Probing the functional link between androgen receptor coactivator and ligand-binding sites in prostate cancer and androgen insensitivity. J Biol Chem. 2006; 281:6648-6663. [PubMed: 16365032]

Heemers HV, Tindall DJ. Androgen receptor (AR) coregulators: a diversity of functions converging on and regulating the AR transcriptional complex. Endocr Rev. 2007; 28:778-808. [PubMed: 17940184]

Hodgson MC, Shen HC, Hollenberg AN, Balk SP. Structural basis for nuclear receptor corepressor recruitment by antagonist-liganded androgen receptor. Mol Cancer Ther. 2008; 7:3187-3194. [PubMed: 18852122]

Horikoshi N, Cong J, Kley N, Shenk T. Isolation of differentially expressed cDNAs from p53dependent apoptotic cells: activation of the human homologue of the Drosophila peroxidasin gene. Biochem Biophys Res Comm. 1999; 261:864-869. [PubMed: 10441517]

Huang W, Shostak Y, Tarr P, Sawyers C, Carey M. Cooperative assembly of androgen receptor into a nucleoprotein complex that regulates the prostate-specific antigen enhancer. J Biol Chem. 1999; 74:25756-25768. [PubMed: 10464314]

Huang H, Tindall DJ. Dynamic FoxO transcription factors. J Cell Sci. 2007; 120:2479-2487. [PubMed: 17646672]

Ishikawa K, Ishii H, Murakumo Y, Mimori K, Kobayashi M, et al. Rad9 modulates the p21WAF1 pathway by direct association with p53. BMC Mol Biol. 2007; 8:37. [PubMed: 17511890]

Kang HJ, Hong YB, Kim HJ, Bae I. CR6-interacting factor 1 (CRIF1) regulates NF-E2-related factor 2 (NRF2) protein stability by proteasome-mediated degradation. J Biol Chem. 2010; 285:2125821268. [PubMed: 20427290]

Kim SJ, Kwon MC, Ryu MJ, Chung HK, Tadi S, Kim YK, Kim YK, Man Kim J, Lee SH, Park JH, Kweon GR, Ryu SW, Jo YS, Lee CH, Hatakeyama H, Goto Y, Yim YH, Chung J, Kong YY, Shong M. CRIF1 is essential for the synthesis and insertion of oxidative phosphorylation polypeptides in the mammalian mitochondrial membrane. Cell Metab. 2012; 16:274-283. [PubMed: 22819524]

Koc EC, Cimen H, Kumcuoglu B, Abu N, Akpinar G, Haque ME, Spremulli LL, Koc H. Identification and characterization of CHCHD1, AURKAIP1 and CRIF1 as new members of the mammalian mitochondrial ribosome. Front Physiology. 2013; 4:1-15.

Kwon MC, Koo BK, Moon JS, Kim YY, Park KC, Kim NS, Kwon MY, Kong MP, Yoon KJ, Im SK, Ghim J, Han YM, Jang SK, Shong M, Kong YY. Crif1 is a novel transcriptional coactivator of STAT3. EMBO J. 2008; 27:642-653. [PubMed: 18200042]

Kwon MC, Koo BK, Kim YY, Lee SH, Kim NS, Kim JH, Kong YY. Essential role of CR6-interacting factor 1 (Crif1) in E74-like factor 3 (ELF3)-mediated intestinal development. J Biol Chem. 2009; 284:33634-33641. [PubMed: 19801644]

Lagarde WH, Blackwelder AJ, Minges JT, Hnat AT, French FS, Wilson EM. Androgen receptor exon 1 mutation causes androgen insensitivity by creating a phosphorylation site and inhibiting melanoma antigen-A11 activation of N/C interaction-dependent transactivation. J Biol Chem. 2012; 287:10905-10915. [PubMed: 22334658]

Lavery DN, McEwan IJ. Functional characterization of the native $\mathrm{NH}_{2}$-terminal transactivation domain of the human androgen receptor: binding kinetics for interactions with TFIIF and SRC-1a. Biochemistry. 2008a; 47:3352-3359. [PubMed: 18284209] 
Lavery DN, McEwan IJ. Structural characterization of the native $\mathrm{NH}_{2}$-terminal transactivation domain of the human androgen receptor: a collapsed disordered conformation underlies structural plasticity and protein-induced folding. Biochemistry. 2008b; 47:3360-3369. [PubMed: 18284208]

Li J, Fu J, Toumazou C, Yoon HG, Wong J. A role of the amino-terminal (N) and carboxyl-terminal (C) interaction in binding of androgen receptor to chromatin. Mol Endocrinol. 2006; 20:776-785. [PubMed: 16373397]

Liao G, Chen LY, Zhang A, Godavarthy A, Xia F, Ghosh JC, Li H, Chen JD. Regulation of androgen receptor activity by the nuclear receptor corepressor SMRT. J Biol Chem. 2003; 278:5052-5061. [PubMed: 12441355]

Liebermann DA, Hoffman B. Gadd45 in stress signaling. J Mol Signal. 2008; 3:15. [PubMed: 18789159]

Ma Q, Fu W, Li P, Nicosia SV, Jenster G, Zhang X, Bai W. Repression of androgen receptor N- and C-terminal interaction and coactivator recruitment by FoxO1 and its involvement in receptor suppression by the PTEN tumor suppressor. Mol Endocrinol. 2009; 23:213-225. [PubMed: 19074551]

Matsuda T, Junicho A, Yamamoto T, Kishi H, Korkmaz K, Saatcioglu F, Fuse H, Muraguchi A. Cross-talk between signal transducer and activator of transcription and androgen receptor signaling in prostate carcinoma cells. Biochem Biophys Res Comm. 2001; 283:179-187. [PubMed: 11322786]

Mohler JL, Gregory CG, Ford OH, Kim D, Weaver CM, Petrusz P, Wilson EM, French FS. The androgen axis in recurrent prostate cancer. Clin Cancer Res. 2004; 10:440-448. [PubMed: 14760063]

Montecinos VP, Godoy A, Hinklin J, Vethanayagam RR, Smith GJ. Primary xenografts of human prostate tissue as a model to study angiogenesis induced by reactive stroma. PLoS One. 2012; 7:e29623. [PubMed: 22303438]

Nakayama K, Nakayama N, Davidson B, Sheu JJ, Jinawath N, Santillan A, Salani R, Bristow RE, Morin PJ, Kurman RJ, Wang TL, Shih IeM. A BTB/POZ protein, NAC-1, is related to tumor recurrence and is essential for tumor growth and survival. Proc Natl Acad Sci USA. 2006; 103:18739-18744. [PubMed: 17130457]

Ni Z, Lou W, Leman ES, Gao AC. Inhibition of constitutively activated Stat 3 signaling pathway suppresses growth of prostate cancer cells. Cancer Res. 2000; 60:1225-1228. [PubMed: 10728680]

Park KC, Song KH, Chung HK, Kim H, Kim DW, Song JH, Hwang ES, Jung HS, Park SH, Bae I, Lee IK, Choi HS, Shong M. CR6-interacting factor 1 interacts with orphan nuclear receptor Nur77 and inhibits its transactivation. Mol Endocrinol. 2005; 19:12-24. [PubMed: 15459248]

Perissi V, Jepsen K, Glass CK, Rosenfeld M. Deconstructing repression: evolving models of crepressor action. Nat Rev Genet. 2010; 11:109-123. [PubMed: 20084085]

Ponguta LA, Gregory CW, French FS, Wilson EM. Site-specific androgen receptor serine phosphorylation linked to epidermal growth factor-dependent growth of castration-recurrent prostate cancer. J Biol Chem. 2008; 283:20989-21001. [PubMed: 18511414]

Quarmby VE, Kemppainen JA, Sar M, Lubahn DB, French FS, Wilson EM. Expression of recombinant androgen receptor in cultured mammalian cells. Mol Endocrinol. 1990; 4:1399-1407. [PubMed: 2172802]

Quigley CA, De Bellis A, Marschke KB, El-Awady MK, Wilson EM, French FS. Androgen receptor defects: historical, clinical, and molecular perspectives. Endocr Rev. 1995; 16:271-321. [PubMed: 7671849]

Quigley CA, Tan JA, He B, Zhou ZX, Mebarki F, Morel Y, Forest M, Chatelain P, Ritzen EM, French FS, Wilson EM. Partial androgen insensitivity with phenotypic variation caused by androgen receptor mutations that disrupt activation function 2 and the $\mathrm{NH}_{2}$ - and carboxyl-terminal interaction. Mech Ageing Dev. 2004; 125:683-695. [PubMed: 15541764]

Ryu MJ, Kim SJ, Kim YK, Choi MJ, Tadi S, Lee MH, Lee SE, Chung HK, Jung SB, Kim HJ, Jo YS, Kim KS, Lee SH, Kim JM, Kweon GR, Park KC, Lee JU, Kong YY, Lee CH, Chung J, Shong M. Crif1 deficiency reduces adipose OXPHOS capacity and triggers inflammation and insulin resistance in mice. PLoS Genet. 2013; 9:e1003356. [PubMed: 23516375] 
Shin J, Lee SH, Kwon MC, Yang DK, Seo HR, Seo HR, Kim J, Kim YY, Im SK, Abel ED, Kim KT, Park WJ, Kong YY. Cardiomyocyte specific deletion of Crif1 causes mitochondrial cardiomyopathy in mice. PlosOne. 2013; 8:e53577.

Suh JH, Shong M, Choi HS, Lee K. CR6-interacting factor 1 represses the transactivation of androgen receptor by direct interaction. Mol Endocrinol. 2008; 22:33-46. [PubMed: 17885209]

Tan JA, Hall SH, Petrusz P, French FS. Thyroid receptor activator molecule, TRAM-1, is an androgen receptor coactivator. Endocrinology. 2000; 141:3440-3450. [PubMed: 10965917]

Tewari AK, Yardimci GG, Shibata Y, Sheffield NC, Song L, Taylor BS, Georgiev SG, Coetzee GA, Ohler U, Furey TS, Crawford GE, Febbo PG. Chromatin accessibility reveals insights into androgen receptor activation and transcriptional specificity. Genome Biol. 2012; 13:R88. [PubMed: 23034120]

Titus MA, Schell MJ, Lih FB, Tomer KB, Mohler JL. Testosterone and dihydrotestosterone tissue levels in recurrent prostate cancer. Clin Cancer Res. 2005; 11:4653-4657. [PubMed: 16000557]

Titus MA, Gregory CW, Ford OH, Schell MJ, Maygarden SJ, Mohler JL. Steroid 5alpha-reductase isozymes I and II in recurrent prostate cancer. Clin Cancer Res. 2005; 11:4365-4371. [PubMed: 15958619]

Wang L, Hsu CL, Chang C. Androgen receptor corepressors: an overview. Prostate. 2005; 63:117130. [PubMed: 15486994]

Wang L, Hsu CL, Ni J, Wang PH, Yeh S, Keng P, Chang C. Human checkpoint protein hRad9 functions as a negative coregulator to repress androgen receptor transactivation in prostate cancer cells. Mol Cell Biol. 2004; 24:2202-2213. [PubMed: 14966297]

Wang Q, Li W, Zhang Y, Yuan X, Xu K, Yu J, Chen Z, Beroukhim R, Wang H, Lupien M, Wu T, Regan MM, Meyer CA, Carroll JS, Manrai AK, Jänne OA, Balk SP, Mehra R, Han B, Chinnaiyan AM, Rubin MA, True L, Fiorentino M, Fiore C, Loda M, Kantoff PW, Liu XS, Brown M. Androgen receptor regulates a distinct transcription program in androgen-independent prostate cancer. Cell. 2009; 138:245-256. [PubMed: 19632176]

Witt O, Deubzer HE, Milde T, Oehme I. HDAC family: What are the cancer relevant targets? Cancer Lett. 2009; 277:8-21. [PubMed: 18824292]

Wu Y, Kawate H, Ohnaka K, Nawata H, Takayanagi R. Nuclear compartmentalization of N-CoR and its interactions with steroid receptors. Mol Cell Biol. 2006; 26:6633-6655. [PubMed: 16914745]

Yang F, Tuxhorn JA, Ressler SJ, McAlhany SJ, Dang TD, Rowley DR. Stromal expression of connective tissue growth factor promotes angiogenesis and prostate cancer tumorigenesis. Cancer Res. 2005; 65:8887-8895. [PubMed: 16204060]

Yuan X, Balk SP. Mechanisms mediating androgen receptor reactivation after castration. Urol Oncol. 2009; 27:36-41. [PubMed: 19111796] 


\section{Highlights}

- $\mathrm{CK} \beta \mathrm{BP} 2 / \mathrm{CRIF} 1$ is a multifunctional corepressor of androgen receptor (AR) transcriptional activity through inhibition of the AR N/C interaction

CKßBP2/CRIF1 binds STAT3 and STAT3 is expressed with CKßBP2/CRIF1 in prostate cancer

action of STAT3 on prostate cancer may offset CK $\beta B P 2 / C R I F 1$ inhibition of $\mathrm{AR}$ and allow prostate growth 
A

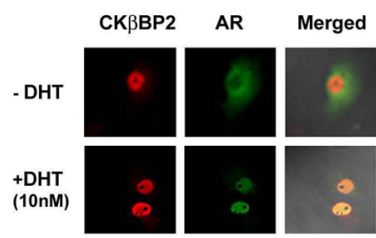

B IP FLAG

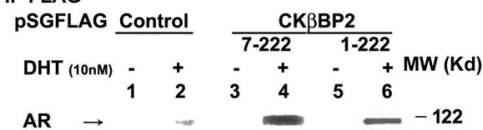

AR $\rightarrow$

Cell lysate

$\mathrm{AR} \rightarrow \infty-122$

$\mathrm{CK} \beta \mathrm{BP} 2 \rightarrow$

C

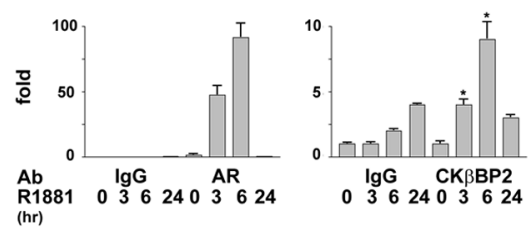

D

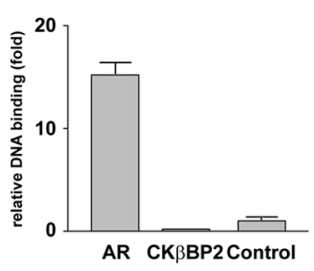

Figure 1. CK $\beta B P 2 / C R I F 1$ interacts with $A R$ and colocalizes with $A R$ in chromatin (A) CK $\beta$ BP2/CRIF1 colocalized with AR in nuclei. pSGFLAG-CK $\beta B P 2 / C R I F 1$ and pSGAR were cotransfected into COS cells in the absence (top) or presence (bottom) of $10 \mathrm{nM}$ DHT. Immunofluoresence for AR (green) and CK $\beta$ BP2/CRIF1 (red) shows CK $\beta$ BP2/CRIF1 shows typical nuclear and perinuclear localization in the absence of DHT and nuclear in the presence of DHT while AR is cytoplasmic in the absence of DHT and nuclear in the presence of DHT. Nuclear colocalization of CK $\beta$ BP2/CRIF1 and AR in the presence of DHT is demonstrated by merged images (yellow). (B) FLAG-CK $\beta$ BP2/CRIF1 coimmunoprecipitated with AR in the presence of DHT. AR was cotransfected in COS cells with control pSGFLAG (lanes 1, 2), truncated FLAG-CKßBP2/CRIF1 (aa 7-222, lanes 3, 4) or full-length FLAG-CK $\beta$ BP2/CRIF1 (aa 1-222, lanes 5, 6) in the absence (-) and presence (+) of $10 \mathrm{nM}$ DHT. Protein extracts were immunoprecipitated with FLAG monoclonal antibody affinity resin and AR (indicated by arrow) was visualized by western blotting with AR specific antibody AR32 (30). CK $\beta$ BP2/CRIF1 in cell extracts was analyzed by western blotting using FLAG monoclonal antibody. (C) Chromatin immunoprecipitation was performed in CWR-R1 cells showing endogenous AR and CK $\beta$ BP2/CRIF1 localization at the PSA gene enhancer at 3 and 6 hrs compared to IgG control *p<0.01. (D) DNA binding was assayed in COS cells as described in Experimental Procedures. In contrast to AR, CK $\beta$ BP2/CRIF1 did not bind to PSA enhancer DNA. 


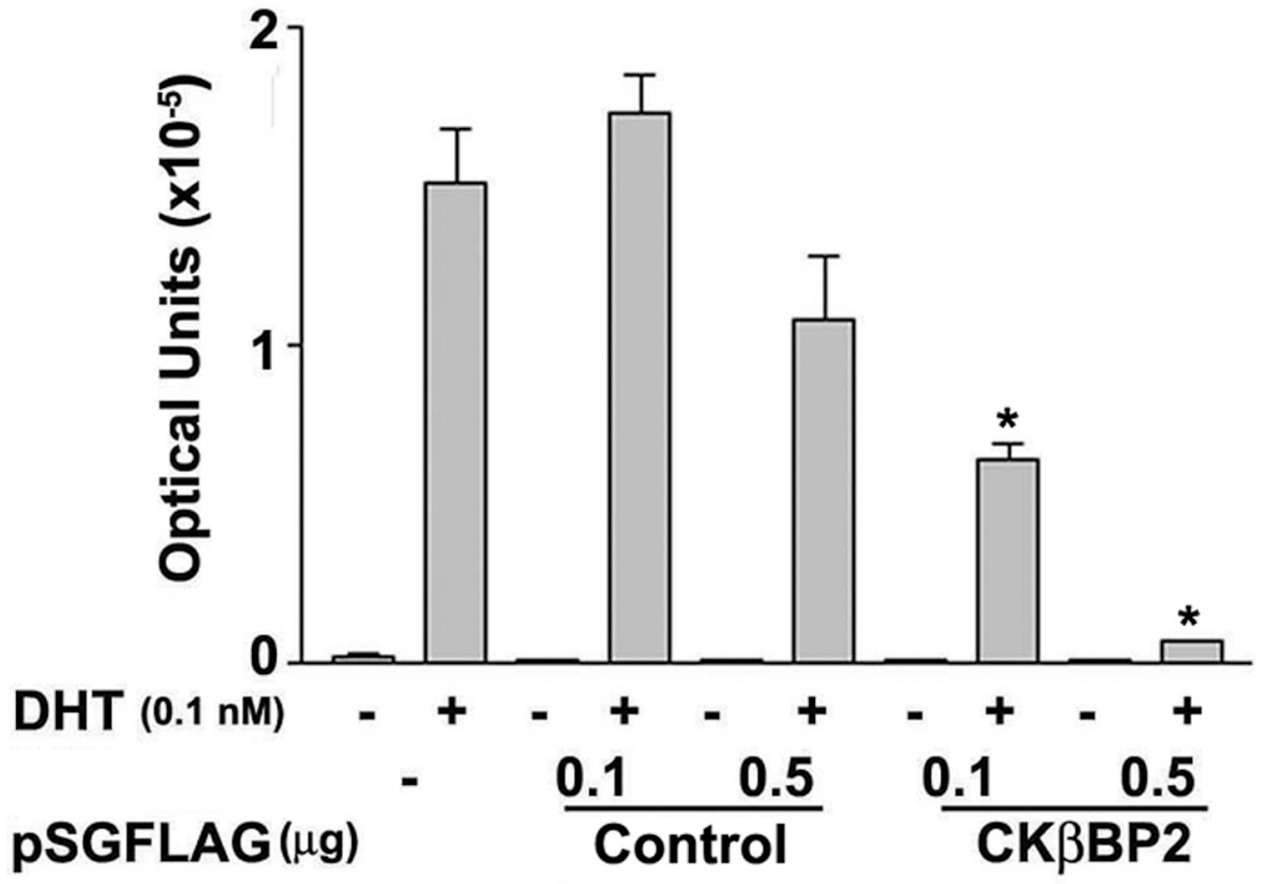

Figure 2. CKßBP2/CRIF1 inhibits AR transcriptional activation of MMTV-Luc in transient cotransfection assays

CV1 cells in $6 \mathrm{~cm}$ dishes were cotransfected with MMTV-Luc $(0.5 \mu \mathrm{g})$ and pSG-AR $(0.1$ $\mu \mathrm{g})$ together with pSG5FLAG control $(0.1$ and $0.5 \mu \mathrm{g})$ or pSGFLAG-CKßBP2/CRIF1-7-222 $(0.1$ and $0.5 \mu \mathrm{g})$. Cells were incubated with and without $0.1 \mathrm{nM} \mathrm{DHT}$ and luciferase activity assayed. Error bars represent \pm SEM. CK $\beta$ BP2/CRIF1 repressed AR transactivation at 0.1 $\mu \mathrm{g} *(\mathrm{p}<0.001)$, and $0.5 \mu \mathrm{g} *(\mathrm{p}<0.001)$ compared to pSG5FLAG control $0.01 \mu \mathrm{g}$ and $0.5 \mu \mathrm{g}$ respectively. 


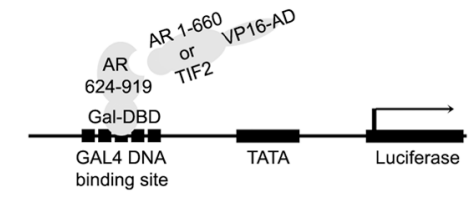

A
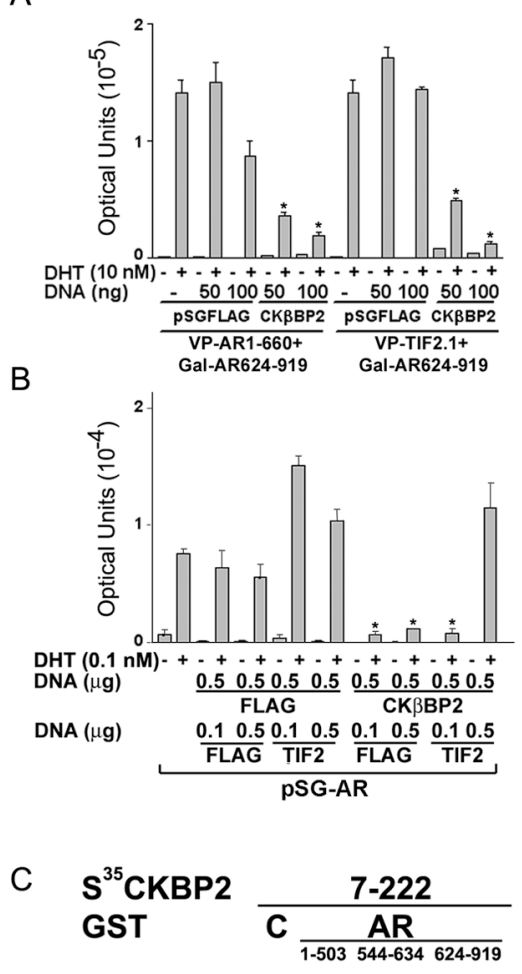

Figure 3. CK $\beta B P 2 / C R I F 1$ inhibits AR N-terminal and TIF2 interactions with the AR C-terminal region

Schematic of mammalian two-hybrid assay is shown at the top. (A) Gal-AR-624-919 (AR C-terminal region) (50 ng) and $0.1 \mu \mathrm{g}$ 5XGAL4Luc were cotransfected into HeLa cells with $50 \mathrm{ng}$ VP-AR-1-660 (AR N-terminal region and DNA binding domain) or $50 \mathrm{ng}$ VP-TIF2.1 (TIF2-624-1287) together with pSGFLAG control or pSGFLAG CK $\beta$ BP2/CRIF1 expression vectors. Cells were incubated with and without $10 \mathrm{nM}$ DHT and luciferase activity was measured. CK $\beta B P 2 / C R I F 1$ inhibited both AR1-660 and TIF2 interactions with AR 624-919 ** $(\mathrm{p}<0.01)$ compared to equal amount of pSGFLAG control. (B) CK $\beta B P 2 / C R I F 1$ inhibition of AR transcriptional activation rescued by TIF2. CV1 cells in $6 \mathrm{~cm}$ dishes were co-transfected with pSG-AR $(0.1 \mu \mathrm{g})$ and MMTV-Luc $(0.5 \mu \mathrm{g})$ together with pSGFLAGCK $\beta$ BP2/CRIF1 $(0.5 \mu \mathrm{g})$ or pSGFLAG control $(0.5 \mu \mathrm{g})$, each with pSGFLAG-TIF2 expression vector $(0.1 \mu \mathrm{g}$ or $0.5 \mu \mathrm{g})$ or the same amounts of control vector. Cells were incubated in the absence and presence of $0.1 \mathrm{nM}$ DHT and luciferase activity assayed. CK $\beta$ BP2/CRIF1 repressed AR transactivation in the presence of pSGFLAG control and TIF2 $0.1 \mu \mathrm{g} *(\mathrm{p}<0.01)$ but not in the presence of TIF2 $0.5 \mu \mathrm{g}(\mathbf{C})$ Preference for binding of $\mathrm{CK} \beta \mathrm{BP} 2 / \mathrm{CRIF} 1$ to the AR ligand binding domain. Glutathione-Sepharose affinity matrix assay of $\left[{ }^{35} \mathrm{~S}\right] \mathrm{CK} \beta \mathrm{BP} 2 / \mathrm{CRIF} 1-7-222$ binding to GST-glutathione-Sepharose control (C), GST-AR-1-503 N-terminal domain, GST-AR-544-634 DNA binding domain, GSTAR-624-919 ligand binding domain. Binding was assayed in the presence of 0.1 nM DHT. Error bars represent \pm SEM. 
A

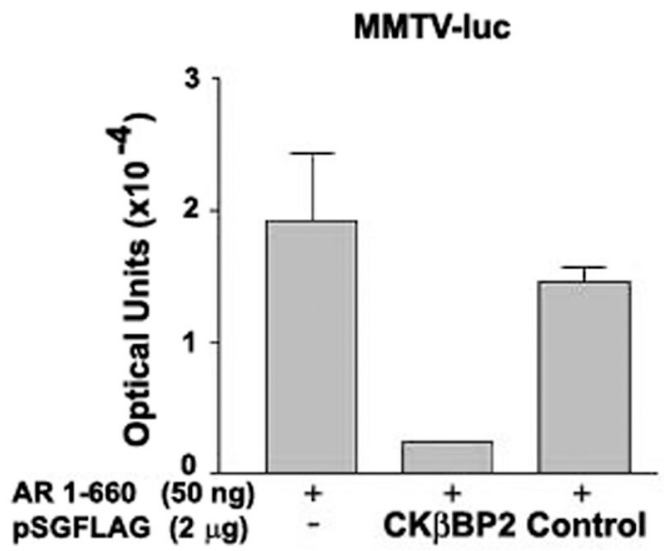

B

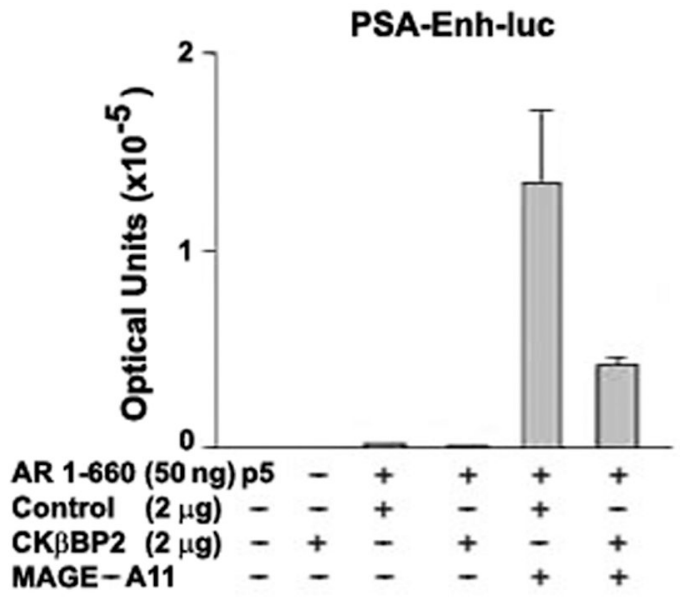

Figure 4. Constitutive transcriptional activity of AR-1-660 is inhibited by CK $\beta B P 2 / C R I F 1$ in the absence and presence of MAGE-A11 or MAGE-A11 plus the p160 coactivator, TIF2

(A) CV1 cells in $6 \mathrm{~cm}$ dishes were transfected with pCMVAR-1-660 (50 ng) and MMTVLuc $(5 \mu \mathrm{g})$ together with pSG-FLAG-CK $\beta$ BP2/CRIF1 or pSG-FLAG-vector control $(2 \mu \mathrm{g})$. Cells were incubated without DHT and luciferase activity assayed. (B) CV1 cells were transfected with pCMVAR-1-660 (50 ng) and PSA-Enh-Luc (5 $\mu \mathrm{g})$ together with pSGFLAG-CKßBP2/CRIF1 or pSG-FLAG-vector control $(2 \mu \mathrm{g})$, each in the presence or absence of the AR coregulator pSG-MAGE-A11 $(2 \mu \mathrm{g})$. p5 indicates pCMV control vector for AR. Cells were incubated in the absence of hormone and luciferase activity assayed. Error bars represent \pm SEM. Results are representative of three experiments, each done in triplicate. 


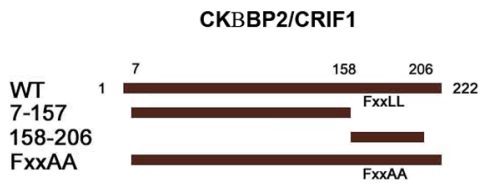

A

B
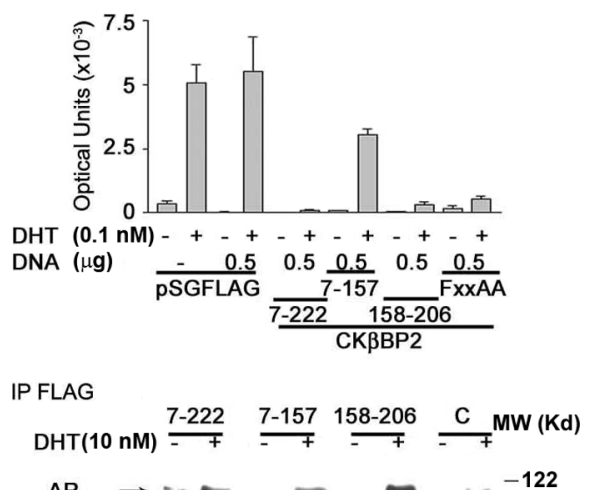

C

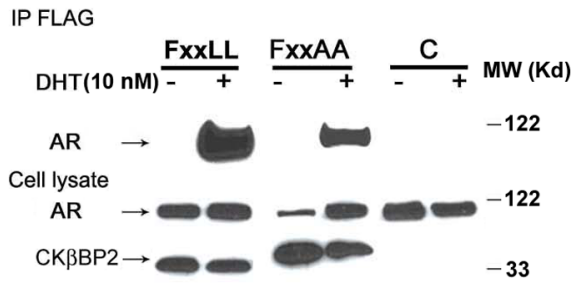

Figure 5. Regional sites of CK $\beta B P 2 / C R I F 1$ and AR interactions

Schematic of CK $\beta B P 2 / C R I F 1$ full-length (amino acid residues 1-222) is shown with CK $\beta$ BP2/CRIF1 fragments 7-157, 158-206 and 7-222 containing a mutation of the FXXAA motif. (A) C-terminal region of CK $\beta B P 2 / C R I F 1-158-206$ was sufficient for AR transcriptional repression. MMTV-Luc $(0.5 \mu \mathrm{g})$ and pSGFLAG-AR $(0.1 \mu \mathrm{g})$ were cotransfected in CV1 cells in $6 \mathrm{~cm}$ dishes with and without control vector pSGFLAG (0.5 $\mu \mathrm{g}), \mathrm{CK} \beta \mathrm{BP} 2 / \mathrm{CRIF} 1-7-222,7-157,158-206$ or 7-222 with FXXLL ( $\left.{ }^{175} \mathrm{FQELL}^{179}\right)$ mutated to FXXAA. Incubations were in the presence or absence of $0.1 \mathrm{nM}$ DHT. Error bars

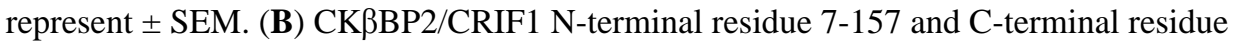
158-206 fragments interact with full-length AR. AR interaction with FLAG-CK $\beta B P 2 / C R I F 1$ amino acid residues 7-222, 7-157 and 158-206 and the pSGFLAG empty vector control was compared by coimmunoprecipitation assay in lysates of cotransfected COS cells incubated in the presence and absence of $10 \mathrm{nM}$ DHT. Immunoprecipitation was preformed using FLAG affinity resin antibody and AR was visualized by western blotting using AR 32 antibody. Expression levels of AR and CK $\beta B P 2 / C R I F 1$ were assayed by western blotting transfected COS cell protein extracts. FLAG-CKßBP2/CRIF1 158-206 was too small to identify on this gel. Its expression is shown on a 4-20\% gradient gel (Fig. S4) (C) The FXXLL motif of CK $\beta B P 2 / C R I F 1$ is not required for AR binding. FLAG-CK $\beta B P 2 /$ CRIF1-7-222 wild-type or with ${ }^{175}$ FQEAA ${ }^{179}$ FXXAA mutation and control pSGFLAG empty vector were cotransfected individually with AR into COS cells and incubated in the presence and absence of $10 \mathrm{nM}$ DHT. Immunoprecipitation was performed using FLAG 
antibody affinity resin and AR was visualized by western blotting with AR 32 antibody. Expression levels of CK $\beta$ BP2/CRIF1 and AR in COS cell protein extracts were assayed by western blotting. Error bars represent \pm SEM. Results are representative of three experiments. 
A

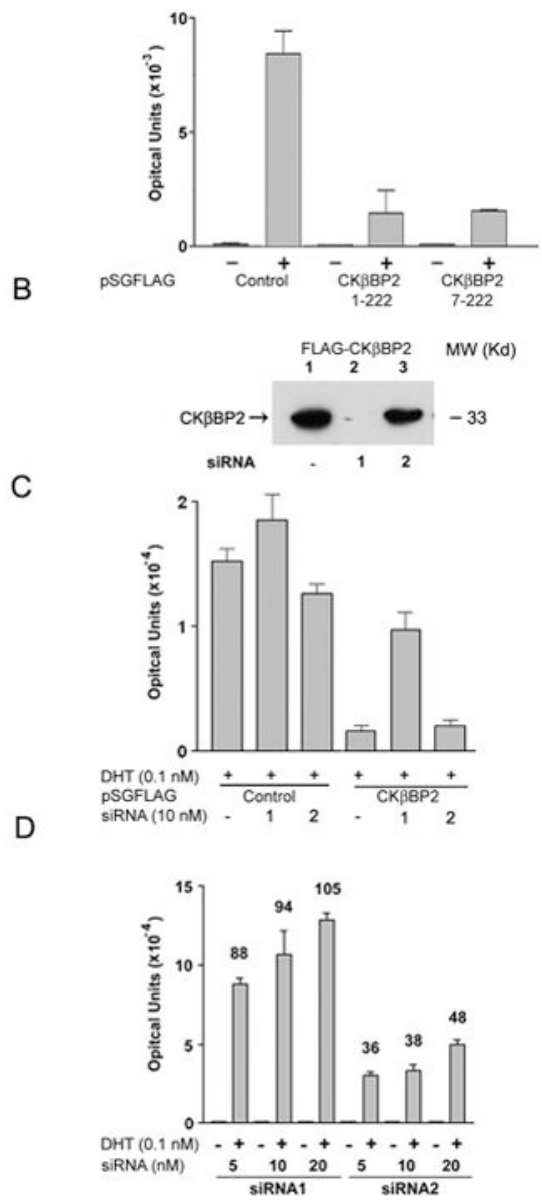

Figure 6. CK $\beta B P 2 / C R I F 1$ inhibits endogenous AR transcriptional activation in CWR-R1 human prostate cancer cells

(A) CWR-R1 cells in 6 well plates were transfected with MMTV-Luc $(0.1 \mu \mathrm{g})$ and $0.25 \mu \mathrm{g}$ pSG5FLAG-control vector, pSGFLAG-CK $\beta$ BP2/CRIF1-1-222 or pSGFLAG-CK $\beta$ BP2/ CRIF1-7-222. Cells were incubated with and without $0.1 \mathrm{nM}$ DHT and luciferase activity measured. Error barsrepresent \pm SEM. (B) Inhibition of recombinant CK $\beta B P 2 / C R I F 1$ protein expression by CK $\beta B P 2 / C R I F 1$ siRNA 1 . COS cells in $6 \mathrm{~cm}$ dishes were transfected with pSGFLAG-CK $\beta$ BP2/CRIF1 (lane 1), pSGFLAG-CK $\beta B P 2 / C R I F 1$ with the addition of 20 nM CKßBP2/CRIF1 siRNA 1 (lane 2) or siRNA 2 (lane 3). Cells were incubated for $48 \mathrm{~h}$ and protein levels in cell lysates assayed by western blotting using FLAG monoclonal antibody. (C) CK $\beta$ BP2/CRIF1 siRNA-1 prevented recombinant CK $\beta B P 2 / C R I F 1$ inhibition of AR transcriptional activation. CV1 cells in $6 \mathrm{~cm}$ dishes were transfected with $0.5 \mu \mathrm{g}$ MMTV-Luc, $0.1 \mu \mathrm{g}$ pSG-AR and $0.5 \mu \mathrm{g}$ pSGFLAG-CK $\beta$ BP2/CRIF1 or control vectors, with addition of $10 \mathrm{nM} \mathrm{CK} \beta \mathrm{BP} 2 / \mathrm{CRIF} 1$ siRNA-1 or siRNA-2. Cells were incubated with $0.01 \mathrm{nM}$ DHT and luciferase activity assayed. Error bars represent \pm SEM. (D) Endogenous AR transcriptional activation in CWR-R1 cells was increased by inhibition of CK $\beta B P 2 /$ CRIF1 expression. CWR-R1 cells in 6 well plates were transfected with MMTV-Luc (0.1 $\mu \mathrm{g})$ using Effectene and increasing amounts (5-20 nM) CK $\beta$ BP2/CRIF1 siRNA-1 or siRNA-2. Cells were incubated in the presence and absence of DHT and luciferase activity assayed. Fold inductions indicated by the number above the bar represent luciferase activity in the presence of DHT divided by activity in the absence of DHT. Error bars represent \pm SEM. Results are representative of two experiments, each performed in triplicate. 


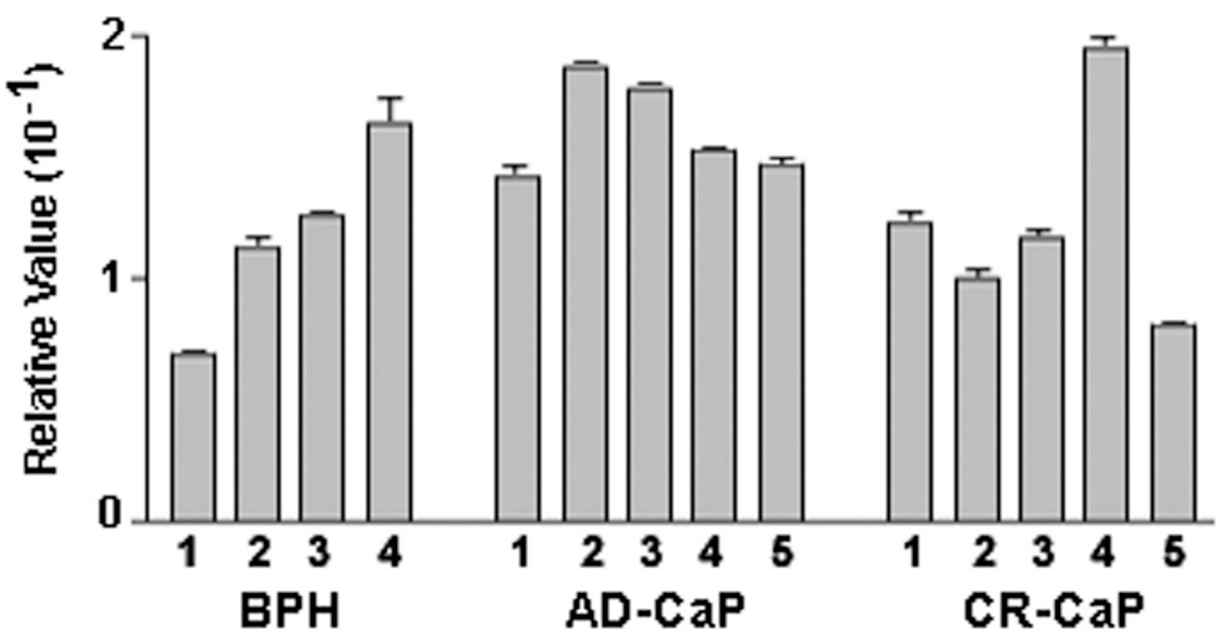

Fig. 7. CKßBP2/CRIF1 mRNA in benign prostatic hyperplasia (BPH), androgen-dependent prostate cancer (AD-CaP) and castration-recurrent prostate cancer ( $\mathrm{CR}-\mathrm{CaP}$ ) RNA was extracted using Trizol (Qiagen) from 4 or 5 different specimens of BPH, AD-CaP and CR-CaP and reverse transcribed using Super Script II Reverse Transcriptase (Invitrogen). RT-PCR using 100 ng cDNA was performed in a Roche Light Cycler with Quanti Tech SYBR Green (Qiagen). Gene expression was calculated using a standard curve. Relative expression was defined as sample gene expression divided by internal control gene expression as described in Methods. Error bars represent \pm SEM. Results are representative of two experiments, each performed in triplicate. 


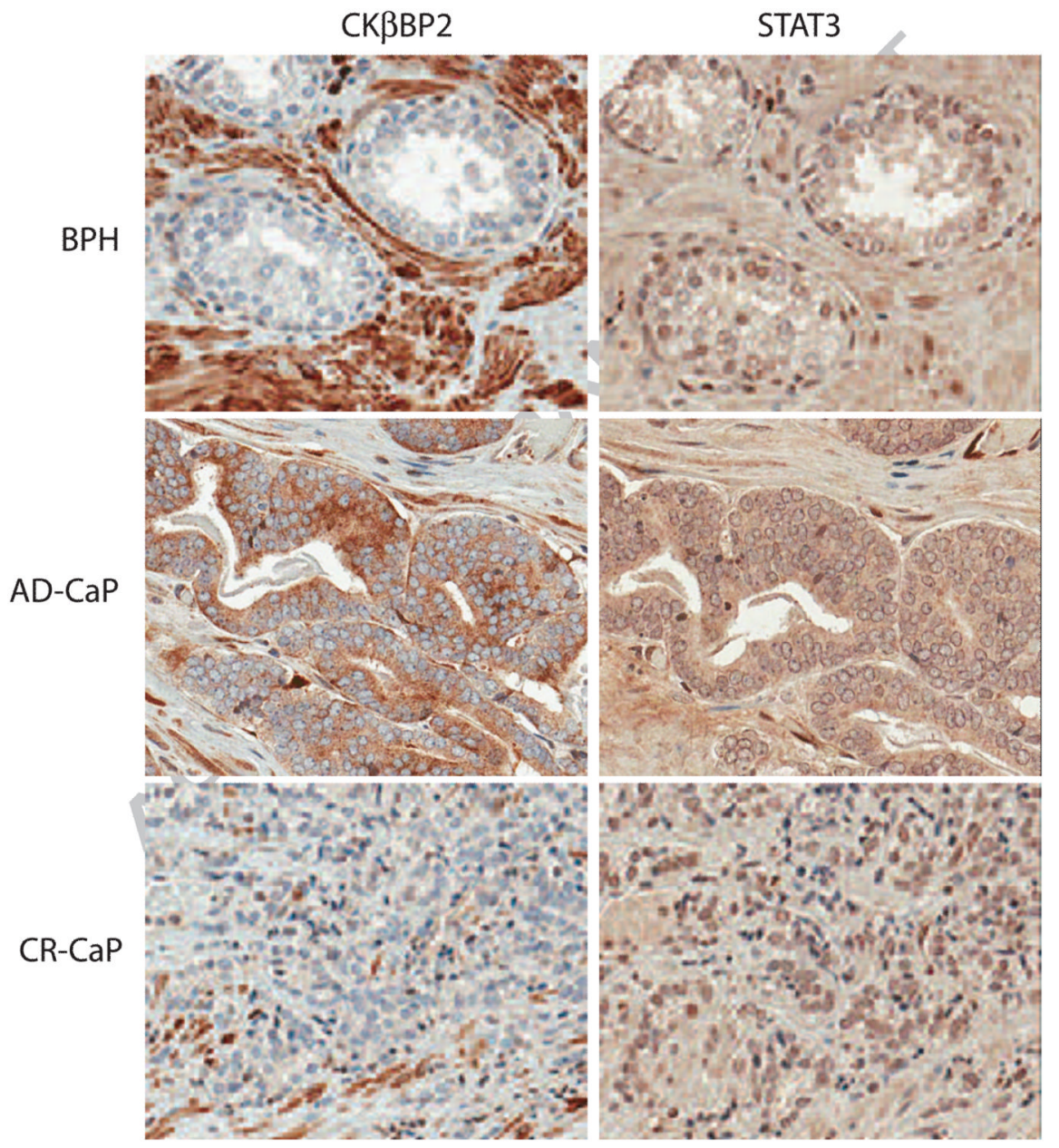

Figure 8. CK $\beta B P 2 / C R I F 1$ and STAT3 expression in adjacent sections of tissue microarrays of human benign prostatic hyperplasia, androgen-dependent and castration-recurrent prostate cancer

Representative pictures show human benign prostatic hyperplasia (BPH, top), androgendependent (AD-CaP, middle) and castration-recurrent prostate cancer (CR-CaP, bottom). Tissue microarray adjacent thin sections were prepared and immunostained as described in

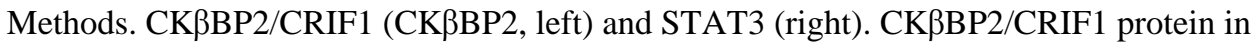
epithelial cells: AD-CaP > BPH ( $<<0.001)$, CR-CaP < AD-CaP (p<0.014); CK $\beta B P 2 / C R I F 1$ protein in stromal cells: staining is mainly in myofibroblasts. No difference overall between staining of stroma in $\mathrm{BPH}, \mathrm{AD}-\mathrm{CaP}$ and $\mathrm{CR}-\mathrm{CaP}$. STAT3 protein was present where $\mathrm{CK} \beta \mathrm{BP} 2 / \mathrm{CRIF} 1$ protein was expressed in $\mathrm{BPH}$ and prostate cancer. 